\title{
Recapitulation of Biological and Clinical Implication of Lung Cancer
}

\author{
Neha Kumari ${ }^{1}$, Jagpreet kour $^{2}$, Bharti Sapra ${ }^{3 *}$ \\ ${ }^{1,2}$ Research Scholar, Department of Pharmaceutical sciences and Drug Research, Punjabi University, Patiala, 147001, Punjab, India \\ ${ }^{3}$ Assistant Professor, Department of Pharmaceutical sciences and Drug Research, Punjabi University, Patiala, 147001, Punjab, India
}

DOI: $\underline{10.36348 / \text { sjmps.2020.v06i03.001 }}$

| Received: 26.02.2020 | Accepted: 05.03.2020 | Published: 13.03.2020

*Corresponding author: Bharti Sapra

\section{Abstract}

Lung cancers are broadly classified as small-cell carcinomas and non-small-cell carcinomas. Non-small-cell lung cancer is more common and it accounts for up to $75 \%$ of lung cancers. Determination of the development of cancer to lungs is solely dependent on mutation of cells leading to the expression of tumor specific proteins. Hence a clear understanding of the vital structural design and physiology of the lungs assists in determination of the stages of this disease. The anatomical architecture of the lungs and their organization with adjacent organs throws light on the site of origin of malignancy, its spreading pattern and clinical presentation etc. This article has summarized the types of lung cancer, pathophysiology along with the microenvironment. The article includes the discussion on the treatment interventions such as surgery, chemotherapy, radiation therapy, the promising potential of immunotherapies and target-oriented therapies in NSCLC. Even though, the lung cancer is escapable however, it is usually diagnosed at an incurable stage.

Keywords: lung cancer; Non-small cell lung cancer (NSCLC) and small cell lung cancer (SCLC); Target Therapies; Immuno checkpoints; Tumor Microenvironment; Oncogene.

Copyright @ 2020: This is an open-access article distributed under the terms of the Creative Commons Attribution license which permits unrestricted use, distribution, and reproduction in any medium for non-commercial use (NonCommercial, or CC-BY-NC) provided the original author and source are credited.

\section{Highlights:}

Objective: In this review article, our main focus was on the pathophysiology and the various treatments of lung cancer.

- Lung cancer is one of the most fatal chronic respiratory diseases, accounting for more than one million cases were diagnosed annually.

- Treatment of lung cancer severs as a big challenge for an oncologist. SCLC (small cell lung cancer) and NSCLC (non- small cell lung cancer) are two types of lung cancer.

- There are various conventional strategies to treat lung cancer at specific stages of lung cancer. These are either used as along or in combination with other chemotherapeutic agents.

- Chemotherapy is still an effective solution for the treatment, especially in NSCLC. Development of molecular targeted therapy; immunotherapy and immune-checkpoints inhibitors are one of the promising therapies options in both NSCLC and SCLC.

\section{INTRODUCTION}

Carcinomas that originate from respiratory epithelium dominantly in bronchi, bronchioles and alveoli are referred to as lung cancer. This type of cancer is mostly diagnosed at later stages hence leading to high mortality rate. Based on the sizes and appearance of cancerous cells cancer has been classified into two type's i.e. non-small cell lung cancer (NSCLC) and small cell lung cancer (SCLC). According to WHO, lung cancer is the leading cause of mortality across world approximately 18.4 million deaths cases were reported in International agency for research on cancer (IARC global agency observatory) in September, 2018. Lung cancer is also known as bronchogenic carcinoma which affects both females and males. The primary function of the lungs is the exchange of gases between air and blood. It exactly occurs in epithelial cells [1]. There are two main factors which are responsible for causing lung cancer such as external agents including exposure to asbestos, arsenic, chromic, nickel, smoking (over 60 known carcinogens, including radioisotopes, nitrosamine, benzopyrene, etc.), tobacco, air pollution (particulate matter 2.5) \{diesel funnels particle with PAH (polycyclic aromatic hydrocarbons) \}, radon gas (breakdown of radium and decay product of uranium, cause genetic mutation) whereas gene mutation, genetic and epigenetic mutations come under internal factors. These agents are responsible for initiation, progression and malignancy of cancer [2-3]. Different stages of NSCLC and SCLC shown in figure 1. Table 1 summarizes the types of lung cancer according to WHO, 2015. 


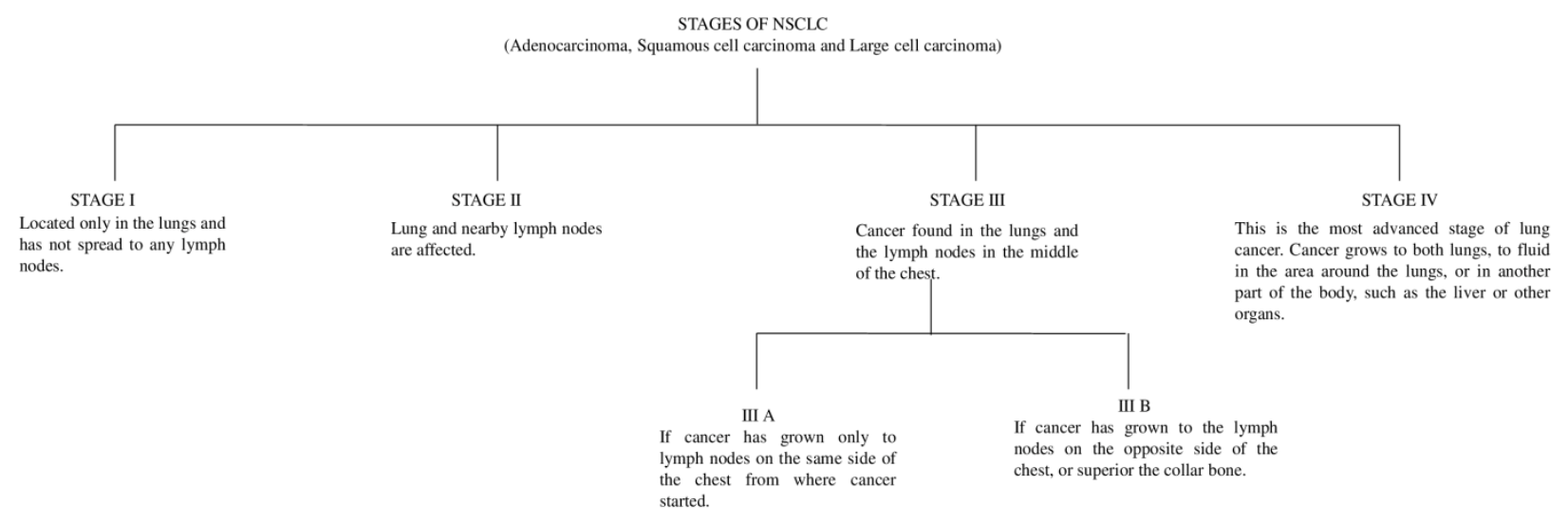

STAGES OF SCLC

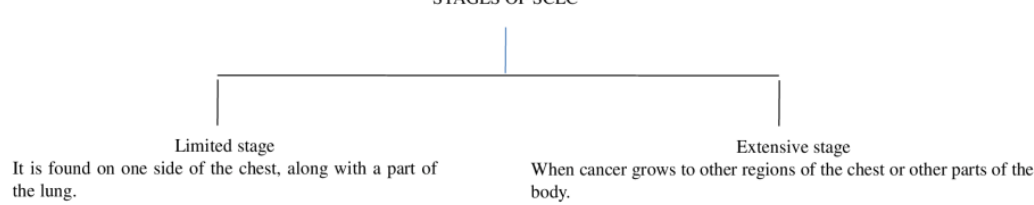

(b)

NSCLC- Non-small cell lung cancer, SCLC- Small cell lung cancer

Fig-1: Stages of lung cancer is depicted in figure (a) NSCLC and (b) SCLC

Table-1: Latest classification of lung cancer proposed by World Health Organization 2015

\begin{tabular}{|c|c|c|c|c|}
\hline Histological type & Subtype & Immunohistochemical changes & Sub-classification of subtype & $\begin{array}{l}\text { Refere } \\
\text { nce }\end{array}$ \\
\hline \multirow[t]{3}{*}{ Epithelial tumors } & \begin{tabular}{ll}
\multicolumn{2}{l}{ Adenocarcinoma } \\
(malignant epithelial \\
neoplasm with glandular \\
differentiation)
\end{tabular} & $\begin{array}{l}\text { Mostly occurring in } 60 \% \text { of NSCLC. } \\
\text { Features: Originates in peripheral lung tissue } \\
\text { with central fibrosis and pleural puckering. } \\
\text { Pneumocyte marker: TTF-1 and/or Napsin } \\
\text { A } \\
\text { Main cause; Nonsmokers, ex-smokers, } \\
\text { smokers, and modest smoking history. }\end{array}$ & $\begin{array}{l}\text { Lepidic adenocarcinoma } \\
\text { Acinar adenocarcinoma } \\
\text { Papillary adenocarcinoma } \\
\text { Micropapillary adenocarcinoma } \\
\text { Solid adenocarcinoma } \\
\text { Invasive mucinous } \\
\text { adenocarcinoma a) Mixed } \\
\text { invasive mucinous } \\
\text { adenocarcinoma b) Non } \\
\text { mucinous adenocarcinoma } \\
\text { Colloid adenocarcinoma } \\
\text { Fetal adenocarcinoma } \\
\text { Enteric adenocarcinoma } \\
\text { Minimally invasive } \\
\text { adenocarcinoma a) Mucinous } \\
\text { adenocarcinoma } \\
\text { Non mucinous adenocarcinoma }\end{array}$ & {$[4-5]$} \\
\hline & Squamous cell carcinoma & $\begin{array}{l}\text { Mostly occurring in } 30 \% \text { of NSCLC } \\
\text { Features: Originate in centeral lung tissue } \\
\text { and shows keratinization and intercellular } \\
\text { bridges (hollow cavity and related cell } \\
\text { death). } \\
\text { Selective squamous cell markers: p40, } \\
\text { CK5/6, CK5, and p63 } \\
\text { Main cause: Associated with smoking. }\end{array}$ & $\begin{array}{l}\text { Keratinizing squamous cell } \\
\text { carcinomae } \\
\text { Nonkeratinizing squamous cell } \\
\text { carcinomae } \\
\text { Basaloid/squamous cell } \\
\text { carcinomae } \\
\text { Preinvasive lesion Squamous } \\
\text { cell carcinoma in situ }\end{array}$ & {$[4-5]$} \\
\hline & Neuroendocrine tumors & $\begin{array}{l}\text { Mostly occurring in } 20-30 \% \text { of lung cancer. } \\
\text { Features: Epitomized by tumor proliferation } \\
\text { rate, tumor aggressiveness and prognosis and } \\
\text { cells having organoid growth pattern, finely } \\
\text { granular or "salt-and-pepper" chromatin } \\
\text { pattern, and several hallmark neuroendocrine } \\
\text { markers. } \\
\text { Neuroendocrine markers: Chromogranin A, } \\
\text { synaptophysin, and CD56 }\end{array}$ & $\begin{array}{l}\text { Small cell carcinoma (Combined } \\
\text { small cell carcinoma) } \\
\text { Large cell neuroendocrine } \\
\text { carcinoma (Combined large cell } \\
\text { neuroendocrine carcinoma) } \\
\text { Carcinoid tumors } \\
\text { a) Typical carcinoid tumor } \\
\text { b) Atypical carcinoid tumor } \\
\text { Preinvasive lesion Diffuse } \\
\text { idiopathic pulmonary } \\
\text { Neuroendocrine cell hyperplasia }\end{array}$ & {$[4-5]$} \\
\hline
\end{tabular}


Neha Kumari et al; Saudi J Med Pharm Sci, March., 2020; 6(3): 246-264

\begin{tabular}{|c|c|c|c|c|}
\hline & Large cell carcinoma & $\begin{array}{l}\text { Mostly occurring in } 15 \% \text { of NSCLC } \\
\text { Effective area- originates in peripheral } \\
\text { region with bulky and necrotic in appearance } \\
\text { have heterogeneous group of tumors with } \\
\text { adenocarcinoma. Squamous cell } \\
\text { differentiation, or a null immunophenotype } \\
\text { and genotype. }\end{array}$ & $*$ & {$[4-5]$} \\
\hline & $\begin{array}{l}\text { Adenosquamous } \\
\text { carcinoma }\end{array}$ & $\begin{array}{l}\text { Rare type of NSCLC, less than } 5 \% \text { of lung } \\
\text { cancer. Hybrid type of carcinoma of } \\
\text { adenocarcinoma and squamous cell } \\
\text { carcinoma }\end{array}$ & $*$ & [4-5] \\
\hline & Sarcomatoid carcinomas & $\begin{array}{l}\text { Rare type of NSCLC, less than } 3 \% \text { of lung } \\
\text { cancer. } \\
\text { Features: Spindle and/or giant cell } \\
\text { differentiation } \\
\text { Epithelial markers : Pancytokeratin, } \\
\text { cytokeratin AE1/AE3, CK7, and EMA }\end{array}$ & $\begin{array}{l}\text { Pleomorphic carcinoma } \\
\text { Spindle cell carcinoma } \\
\text { Giant cell carcinoma } \\
\text { Carcinosarcoma } \\
\text { Pulmonary blastoma }\end{array}$ & [4-5] \\
\hline & $\begin{array}{l}\text { Other and Unclassified } \\
\text { carcinomas }\end{array}$ & $\begin{array}{l}\text { Rare type of NSCLC, less than } 10 \% \text { of lung } \\
\text { cancer. } \\
\text { Features: Rarely arise from bronchial glands }\end{array}$ & $\begin{array}{l}\text { Lymphoepithelioma-like } \\
\text { carcinoma } \\
\text { NUT carcinoma }\end{array}$ & [4-5] \\
\hline & Salivary gland-type tumors & $\begin{array}{l}\text { Less than } 1 \% \text { of lung cancer. } \\
\text { Feature: Arise from submucosal glands of } \\
\text { the tracheo-bronchial tree, rare intrathoracic } \\
\text { malignant neoplasm }\end{array}$ & $\begin{array}{l}\text { Mucoepidermoid carcinoma } \\
\text { Adenoid cystic carcinoma } \\
\text { Epithelial-myoepithelial } \\
\text { carcinoma } \\
\text { Pleomorphic adenoma }\end{array}$ & [4-6] \\
\hline & Papillomas & $\begin{array}{l}\text { Mostly occurring in less than } 1 \% \text { of lung } \\
\text { cancer. } \\
\text { Features: Proximal or peripheral } \\
\text { (fibrovascular core covered by an } \\
\text { epithelium), polypoid, tan-white and friable } \\
\text { lesions are protrude into airways lumens } \\
\text { Cause: Smoking }\end{array}$ & $\begin{array}{l}\text { Squamous cell papilloma } \\
\text { (Exophytic and Inverted) } \\
\text { Glandular papilloma } \\
\text { Mixed squamous and glandular } \\
\text { papilloma }\end{array}$ & [4-7] \\
\hline & Adenomas & $\begin{array}{l}\text { Less than } 1 \% \text { of lung cancer. } \\
\text { Features: Originate in the mucous glands and } \\
\text { ducts of the lung airways (bronchi) or windpipe } \\
\text { (trachea), and in the salivary glands }\end{array}$ & $\begin{array}{l}\text { Sclerosing pneumocytomae } \\
\text { Alveolar adenoma } \\
\text { Papillary adenoma } \\
\text { Mucinous cystadenoma } \\
\text { Mucous gland adenoma }\end{array}$ & [4-6] \\
\hline \multirow[t]{3}{*}{$\begin{array}{l}\text { Mesenchymal } \\
\text { tumors }\end{array}$} & $\begin{array}{l}\text { Vascular tumors and } \\
\text { vessel-associated tumors }\end{array}$ & $\begin{array}{l}\text { Rarely occurring tumor. } \\
\text { Features: Multiple nodules with an intra- } \\
\text { alveolar architecture and central region of } \\
\text { hyalinization } \\
\text { Originate from arterial intima of elastic type } \\
\text { arteries } \\
\text { Subungal regions } \\
\text { Localized mass composed of perivascular } \\
\text { epithelioid cells with clear-to-pale } \\
\text { eosinophilic cytoplasm } \\
\text { Proliferation of lymphatic vessels } \\
\text { Proliferation of capillaries } \\
\text { Markers- 1. Positive stain for endothelial } \\
\text { markers CD31, CD34 and factor VIII. } \\
\text { 2. No specific biomarkers } \\
\text { 3. Smooth muscle cell markers } \alpha \text {-SMA, h- } \\
\text { Caldesmon, calponin, desmin. } \\
\text { 4. Melanocyte markers HMB45, Melan A } \\
\text { and S100. } \\
\text { 5. Lymphatic endothelial marker D2-40, } \\
\text { CD31 and factor VIII } \\
6 . \text { Both endothelial and smooth muscle cell } \\
\text { markers. }\end{array}$ & $\begin{array}{l}\text { Epithelioid } \\
\text { hemangioendothelioma } \\
\text { Pulmonary artery intimal } \\
\text { sarcoma } \\
\text { Glomus tumor } \\
\text { PEComatous tumor } \\
\text { Diffuse pulmonary capillary } \\
\text { hemangioma } \\
\text { Solitary pulmonary capillary } \\
\text { hemangioma }\end{array}$ & \multirow[t]{3}{*}[4,8]{} \\
\hline & $\begin{array}{l}\text { Nonvascular spindle cell } \\
\text { tumors }\end{array}$ & $\begin{array}{l}\text { Rarely develop in the lung (fibroblastic } \\
\text { tumors) } \\
\text { Features: Develop in pleura, extra- } \\
\text { pleuropulmonary organs and soft tissues } \\
\text { Markers: } \\
\text { 1.CD34,BCL2,CD99,STAT6 } \\
\text { 2. } \alpha \text { SMA, ALK } \\
\text { 3. CD99, BC12 epithelial markers and TLE1 }\end{array}$ & $\begin{array}{l}\text { Intrapulmonary solitary fibrous } \\
\text { tumor } \\
\text { Inflammatory myofibroblastic } \\
\text { tumor } \\
\text { Synovial sarcoma } \\
\text { Pulmonary myxoid sarcoma } \\
\text { with } \quad \text { EWSR1-CREB1 } \\
\text { translocation. }\end{array}$ & \\
\hline & $\begin{array}{l}\text { Other } \begin{array}{r}\text { mesenchymal } \\
\text { tumors and tumor-like } \\
\text { lesions }\end{array}\end{array}$ & $\begin{array}{l}\text { Rarely occurring tumor } \\
\text { Features: Similar genomic features with } \\
\text { sarcomas and proliferation of cells } \\
\text { Markers: Cytokeratin, } \alpha-S M A \text {, calponin, } \\
\text { p63, and S100. }\end{array}$ & $\begin{array}{l}\text { Myoepithelial } \\
\text { tumor/myoepithelial carcinoma } \\
\text { Pulmonary hamartoma } \\
\text { Chondroma } \\
\text { Granular cell tumor }\end{array}$ & \\
\hline
\end{tabular}


Neha Kumari et al; Saudi J Med Pharm Sci, March., 2020; 6(3): 246-264

\begin{tabular}{|c|c|c|c|c|}
\hline & & & $\begin{array}{l}\text { Nodular pulmonary amyloidosis } \\
\text { IgG-4 related disease }\end{array}$ & \\
\hline & $\begin{array}{l}\text { Metastatic mesenchymal } \\
\text { tumors (pediatric tumors) }\end{array}$ & $\begin{array}{l}\text { Features: Solid masses, various types of } \\
\text { metastatic tumors (e.g., leiomyosarcoma, } \\
\text { synovial sarcoma, low-grade endometrial } \\
\text { stromal sarcoma, and undifferentiated uterine } \\
\text { sarcoma) occasionally appear as cystic } \\
\text { lesions }\end{array}$ & $\begin{array}{l}\text { Congential peribronchial } \\
\text { myofibroblastic tumor } \\
\text { Pleuropulmonary blastoma }\end{array}$ & \\
\hline \multirow[t]{6}{*}{$\begin{array}{l}\text { Lymphohistiocytic } \\
\text { tumors }\end{array}$} & $\begin{array}{l}\text { Lymphohistiocytic tumors } \\
\text { Extranodal marginal zone } \\
\text { lymphomas of mucosa- } \\
\text { associated }\end{array}$ & $\begin{array}{l}\text { Less than } 1 \% \text { of all lymphomas. } \\
\text { Features- arises from peripheral small } \\
\text { bronchi or alveolar epithelial cells } \\
\text { Markers- B cell markers (CD19, CD20, } \\
\text { CD22, CD79a) complement receptors (CD21 } \\
\text { and CD35), and are usually negative for } \\
\text { CD5, CD10, and CD23 }\end{array}$ & $\begin{array}{lrr}\text { Lymphohistiocytic } & \text { tumors } \\
\text { Extranodal } & \text { marginal } & \text { zone } \\
\text { lymphomas of } & \text { mucosa- } \\
\text { associated Lymphoid } & \text { tissue } \\
\text { (MALT lymphoma) } & \end{array}$ & {$[4-5,9]$} \\
\hline & $\begin{array}{l}\text { Diffuse } \\
\text { lymphoma }\end{array}$ & $\begin{array}{l}\text { 11-19\% of primary pulmonary lymphomas. } \\
\text { Feature: Lymphomas chronic inflammation } \\
\text { of the marginal zone B cells of the } \\
\text { "bronchial-associated lymphoid tissue" } \\
\text { Markers: CD20, CD } 43 \text {, Bcl-2, Bcl-6, and } \\
\text { MUM-1 (focally) and negative for CD10 and } \\
\text { Cyclin D1 }\end{array}$ & $*$ & {$[4-5,10]$} \\
\hline & $\begin{array}{l}\text { Lymphomatoid } \\
\text { granulomatosis }\end{array}$ & $\begin{array}{l}0.5-1 \% \text { of primary pulmonary lymphomas. } \\
\text { Feature: B-lymphoproliferative disorder (B } \\
\text { cells and T cells) } \\
\text { Markers: CD20, CD3, CD68, ALK1, CD30, } \\
\text { CD15, EBV }\end{array}$ & * & {$[4-5,11]$} \\
\hline & $\begin{array}{l}\text { Intravascular large B cell } \\
\text { lymphoma }\end{array}$ & $\begin{array}{l}\text { Rarely occurring tumors. } \\
\text { Features: Occlusive proliferation in vessels } \\
\text { (capillaries, small arteries and veins) } \\
\text { Markers: C-reactive protein (CRP), LDH, } \\
\beta_{2} \text {-MG, interleukin-2R (IL-2R) or serum } \\
\text { albumin }\end{array}$ & * & {$[4-5,12]$} \\
\hline & $\begin{array}{l}\text { Pulmonary Langerhans cell } \\
\text { histiocytosis }\end{array}$ & $\begin{array}{l}\text { Rarely occurring tumors. } \\
\text { Features: Damaging of distal bronchioles } \\
\text { and infiltrating of Langerhans' cell within } \\
\text { the lung parenchyma } \\
\text { Markers- specific marker langerin (CD207) }\end{array}$ & * & {$[4-5,13]$} \\
\hline & Erdheim-Chester disease & $\begin{array}{l}\text { Less than !\% of lung cancer } \\
\text { Features: Infiltration of lipid-laden } \\
\text { histiocytes with foamy or eosinophillic } \\
\text { cytoplasm } \\
\text { Markers: Positive and negative stain for } \\
\text { CD68 and CD1a respectively }\end{array}$ & * & {$[4-5,14]$} \\
\hline $\begin{array}{l}\text { Tumors of ectopic } \\
\text { origin }\end{array}$ & $\begin{array}{l}\text { Germ cell tumors } \\
\text { Intrapulmonary thymoma } \\
\text { Melanoma } \\
\text { Meningioma, NOS }\end{array}$ & $\begin{array}{l}4.5 \% \text { of patients with SCLC (Uncommon } \\
\text { type of tumors). } \\
\text { Features: Proliferation of spindle cells, } \\
\text { pseudoglands, cystic lesion } \\
\text { Markers: Epithelial cells AE1/AE3 or } \\
\text { EMA, T cell phenotypes, CD20-positive B } \\
\text { cells }\end{array}$ & $*$ & {$[4-5,15]$} \\
\hline
\end{tabular}

\section{Pathophysiology of Lung Cancer}

All cells in the body consist of genetic material called deoxyribonucleic acid (DNA). At the time of maturity cell divides into two new cells and its DNA is exactly duplicated. The normal aging process or environmental factors sometimes lead to DNA mutation (somatic cells mutation) [4-5]. It further leads to activation of promoting oncogenes due to imbalance in hormones or chronic inflammation and inactivation of tumor suppressor genes. These two factors are responsible for alteration in genes and produce abnormal structural proteins which cause tumor. Pathophysiology of lung cancer with their some diagnostic tests and treatment are described in figure 2 whereas, its clinical symptoms are depicted in figure 3 . 


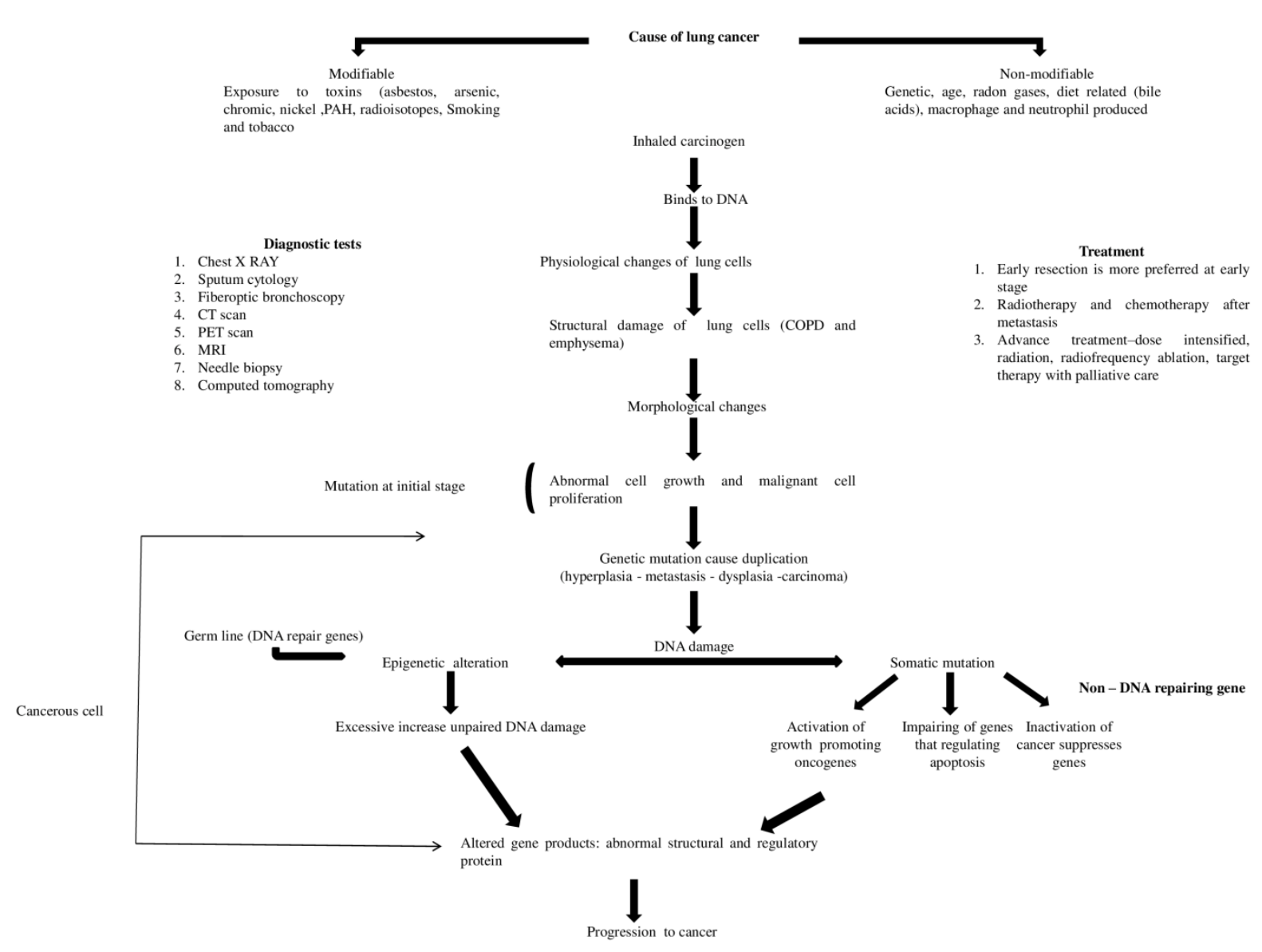

Fig-2: Pathophysiology of lung cancer along with diagnosis tests and suggested treatment

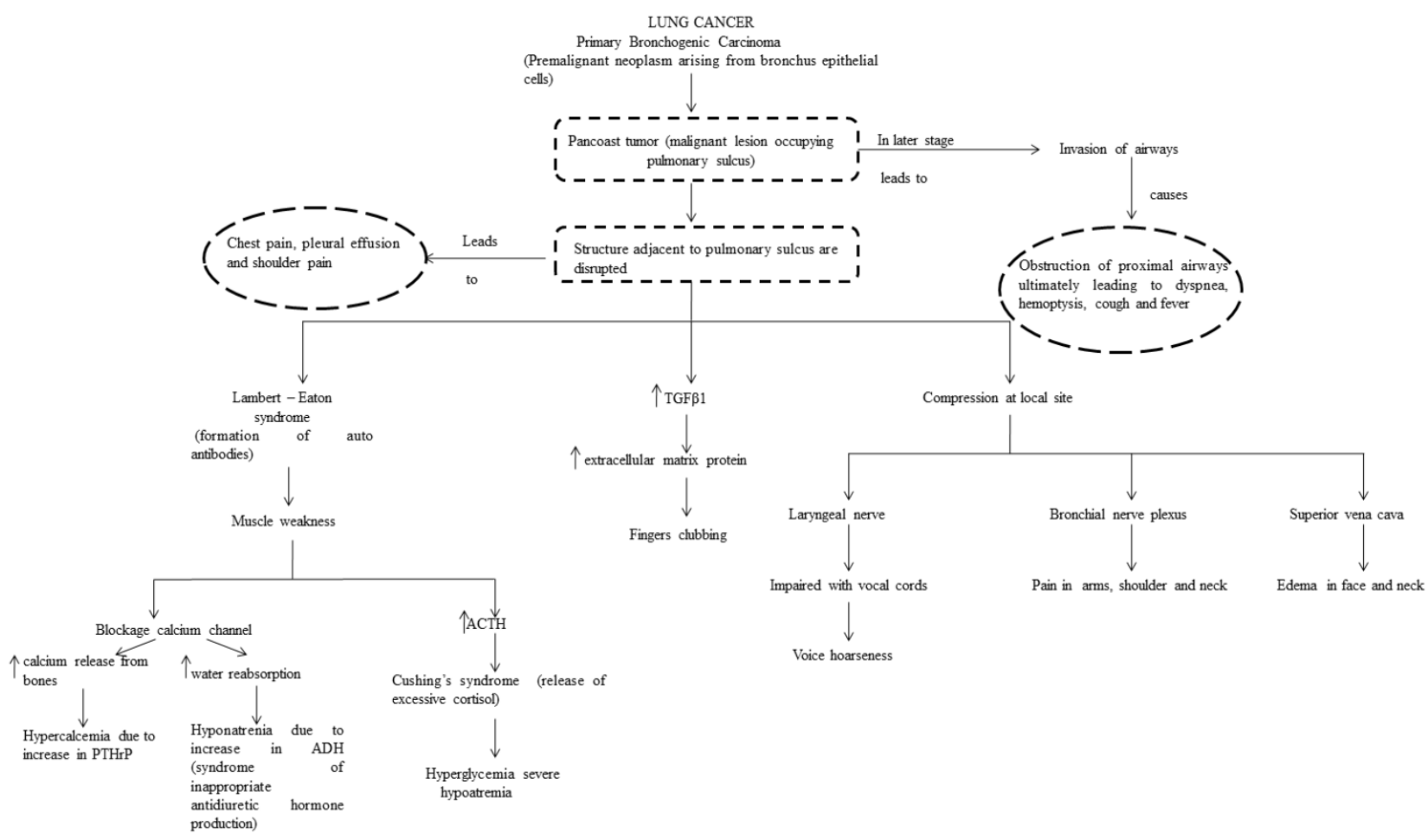

Fig-3: Clinical symptoms of lung cancer 


\section{Microenvironment of Lung Tumor}

The concept of lung immune

microenvironment is in existence since the "seed-soil" theory of Stephen Paget's tumor-specific tumor metastasis in 1889. The understanding of microenvironment of lung cancer is very important to further understand how the affected cells can overcome the check point blockade. The tumor microenvironment (TME) is heterogeneous in composition and comprises of cellular components like endothelial cells, as well as its precursor cells, pericytes, myeloid-derived suppressor cells (MDSC), tumor-associated fibroblast (CAF), tumor-associated macrophages (TAM), T cells and $\mathrm{B}$ Cells, NK (natural killer) cells, $\mathrm{DC}_{\mathrm{s}}$ (dendritic cells), growth factors, proteases, and extracellular matrix [16]. The interactions between genetically altered tumor cells and genetically stable intratumoral stromal cells lead to either activated or reprogrammed stroma that may further promote carcinogenesis by contributing to inflammation, immune suppression, therapeutic resistance, or generating premetastatic niches that support the initiation and establishment of distant metastasis. It also affects the activation and metabolism of $\mathrm{T}$ cells through various mechanisms. Tumor-infiltrating $\mathrm{T}$ lymphocytes have an immune surveillance effect that inhibits the binding to PD-1 and PD-L1, which is positively correlated with resistance, and this resistance develop tumor. Tumor infiltrating $\mathrm{T}$ cells can be activated by co-stimulatory receptors (e.g. tumor necrosis factor receptor superfamily members OX40, CD40, 41BB and B7-CD28, and immunoglobulin superfamily member ICOS etc.) and a co-stimulatory receptor in combination with its ligand by enhancing the function of Th1 (T helper type 1) cells or inhibiting the function of Treg (regulatory $\mathrm{T}$ cells) cells, killing tumor cells. Its combination with ICB (immune check point blockers) can enhance its antitumor efficiency. Treg cells can promote the production of vascular endothelial growth factor (VEGF) in tumor cells and CAF (cancer associated fibroblasts), and reduce IFN- $\gamma$ and granzyme produced by $\mathrm{T}$ cells to reduce immune killing. In tumor patients, Treg cells inhibit specific $\mathrm{T}$ cell responses and express greater level of glucocorticoid-induced tumor necrosis factor receptor-associated proteins (GITR) and CTLA-4 [17].

\section{Treatment of Lung Cancer}

The basic choice of treatment of a patient depends upon the type of cancer and whether the disease has metastasized to distant organs. Lung cancer can be treated with various methods such as surgery, radiofrequency ablation, immunotherapy, stereotactic ablative, radiation therapy, photodynamic therapy, Radiofrequency ablation (RFA), tyrosine kinase inhibitors (TKI) and targeted specific therapy [3, 18, 19].

\section{Surgery}

The surgery is the primary treatment for restricted patients with early-stage cancer and is performed basically for the stage- I NSCLC, stage-II NSCLC and limited-stage SCLC and lymph node tumors may not be benefited from surgery, after which ancillary chemotherapy is given [20]. The surgery involves the removal of the entire lobe in which the tumor is located and a margin of healthy tissue. Agenda for removal of lung cancer includes wedge resection to remove cancerous tissue, segmental resection to remove a major portion of the lung, but not an entire lobe, lobectomy (removal of entire lung lobe), pneumonectomy (removal of entire lung). The objective of surgery is to totally eradicate all the tumor cells and thereby provide a cure [3, 18-19]. Prior surgical techniques such as video-assisted thoracic surgery (VATS) minimal involved invasion and were used to perform a lobectomy or wedge resection, the procedure involves inserting a long thin tube with an attached camera (thoracoscope) connected to a video monitor so that the surgeon can see inside the chest and remove cancerous tissue from the lung [18]. Robotic-assisted thoracic surgery (RATS) is another minimally invasive way of treating lung cancer [19].

\section{Chemotherapy}

Chemotherapy is the most powerful tool to treat lung cancer, new or existing drugs are used to treat/kill cancerous cells [20]. These drugs, may be targeted to cancerous cells (less damage to normal cells) and involve immunotherapy (use the own body's immune system to destroy cancer cells). It is used in all stages of cancer [21]. Chemotherapy works in three different ways such as neoadjuvant or primary systemic lung cancer chemotherapy (before surgery to destroy or remove cancerous cells) [18, 22], adjuvant chemotherapy (to prevent cancer spreading throughout) $[18,23]$ and lastly large circulation of chemotherapeutic drugs $[18,24]$.Cisplatin was approved by the FDA in 1978 and is the most successful drug discovery against cancer still and is widely used in combination with other chemotherapeutic agents. To overcome various side effects like nephrotoxicity, neurotoxicity, retinotoxicity, and ototoxicity, cisplatin derivatives are used [19, 25]. Chemotherapeutic agents which are commonly used to treat lung cancer are carboplatin (Paraplat or Paraplatin), cisplatin (Platinol-AQ or Platinol), docetaxel (Taxotere), etoposide (Toposar or VePesid), gemcitabine hydrochloride (Gemzar) with cisplatin (Platinol-AQ or Platinol), paclitaxel (Taxol) in combination with cisplatin (Platinol-AQ or Platinol), paclitaxel albumin-stabilized nanoparticle formulation (Abraxaned also called albumin-bound paclitaxel or nabpaclitaxel) in combination with carboplatin pemetrexed disodium (Alimta), topotecan hydrochloride (Hycamtin), and vinorelbine tartrate (Navelbine) [26]. US- FDA approved 
chemotherapeutic drugs for lung cancers are summarized in table 2.

Table-2: USFDA approved chemotherapeutic drugs for lung cancer

\begin{tabular}{|c|c|c|c|c|c|c|}
\hline Drug Name/ Brand & Stages & Formulation & Dose & FDA Approval & $\begin{array}{l}\text { Patent } \\
\text { expiry(US) }\end{array}$ & Reference \\
\hline \multicolumn{7}{|c|}{ ANGIOGENESIS INHIBITOR/VEGF RECEPTOR INHIBITOR } \\
\hline Bevacizumab (Avastin) & $\begin{array}{l}\text { Non-squamous NSCLC } \\
\text { at stage IV }\end{array}$ & $\begin{array}{l}\text { Solution for IV } \\
\text { infusion after } \\
\text { dilution }\end{array}$ & $\begin{array}{l}100 \mathrm{mg}, 400 \\
\mathrm{mg}\end{array}$ & February, 2004 & July, 2019 & [27] \\
\hline Ramucirumab (Cyramza) & $\begin{array}{l}2^{\text {nd }} \text { line of treatment } \\
\text { metastatic NSCLC at } \\
\text { stage IV and } \\
\text { hepatocellular } \\
\text { carcinoma with elevated } \\
\text { alpha-fetoprotein }\end{array}$ & $\begin{array}{l}\text { Solution for IV } \\
\text { infusion after } \\
\text { dilution }\end{array}$ & $10 \mathrm{mg} / \mathrm{ml}$ & December, 2014 & $\begin{array}{l}\text { November, } \\
2031\end{array}$ & [28] \\
\hline \multicolumn{7}{|l|}{ ANTIMETABOLITES } \\
\hline Gemcitabine (Gemzar) & \multirow[t]{2}{*}{$\begin{array}{l}\text { NSCLC at stage IIIA, } \\
\text { IIIB, IV and SCLC } \\
\text { (adenocar-cinoma \& } \\
\text { squamous cell } \\
\text { carcinoma) }\end{array}$} & $\begin{array}{l}\text { Powder for IV } \\
\text { infusion after } \\
\text { reconstitution, }\end{array}$ & $\begin{array}{l}200 \mathrm{mg} \text { or } \\
1 \mathrm{mg},\end{array}$ & \multirow[t]{2}{*}{ August, 1998} & \multirow[t]{2}{*}{ May, 2013} & \multirow[t]{2}{*}{ [29] } \\
\hline Infugem & & $\begin{array}{lll}\text { solution } & \text { for } & \text { IV } \\
\text { infusion } & & \end{array}$ & $\begin{array}{l}1200 \mathrm{mg} / 120 \\
\mathrm{ml} \text { to } 2200 \\
\mathrm{mg} / 220 \mathrm{ml}\end{array}$ & & & \\
\hline \multirow[t]{2}{*}{ Methotrexate } & \multirow[t]{3}{*}{$\begin{array}{l}\text { Squamous cell and } \\
\text { small cell lung cancer }\end{array}$} & $\begin{array}{l}\text { Solution for IV, IM, } \\
\text { intra-arterial, or } \\
\text { Intrathecal } \\
\text { administration after } \\
\text { dilution }\end{array}$ & $25 \mathrm{mg} / \mathrm{ml}$ & April, 2005 & \multirow[t]{3}{*}{$\begin{array}{l}\text { January, } \\
2026\end{array}$} & \multirow[t]{3}{*}{ [24] } \\
\hline & & $\begin{array}{l}\text { powder for IV, IM, } \\
\text { Intra-arterial, or } \\
\text { Intrathecal } \\
\text { administration after } \\
\text { dilution }\end{array}$ & & & & \\
\hline (Trexall) & & scored tablets & $\begin{array}{l}1 \mathrm{~g} \quad 5 \mathrm{mg}, \\
7.5 \mathrm{mg}, 10 \mathrm{mg}, \\
15 \mathrm{mg}\end{array}$ & March, 2001 & & \\
\hline Pemetrexed (Alimta) & $\begin{array}{l}\text { first-line treatment of } \\
\text { non-squamous-cell lung } \\
\text { cancer, second-line } \\
\text { treatment of NSCLC at } \\
\text { stage IV }\end{array}$ & $\begin{array}{l}\text { Powder for IV } \\
\text { infusion after } \\
\text { reconstitution and } \\
\text { dilution, }\end{array}$ & $\begin{array}{l}100 \mathrm{mg} \\
500 \mathrm{mg}\end{array}$ & August, 2004 & May, 2022 & [30] \\
\hline \multicolumn{7}{|c|}{ ANTIMICROTUBULE AGENTS } \\
\hline Docetaxel (Taxotere) & $\begin{array}{l}\text { Advance and metastatic } \\
\text { NSCLC at stage IIIA, } \\
\text { IIIB, IV }\end{array}$ & $\begin{array}{llr}\begin{array}{l}\text { Solution } \\
\text { infusion }\end{array} & \text { for } & \text { IV } \\
\text { dilution } & & \text { after } \\
\end{array}$ & $40 \mathrm{mg} / \mathrm{ml}$ & $\begin{array}{l}\text { December, } \\
1999\end{array}$ & May, 2014 & {$[31-32]$} \\
\hline Paclitaxel (Taxol) & $\begin{array}{l}\text { Squamous NSCLC } \\
\text { stage IV }\end{array}$ & $\begin{array}{l}\text { Solution for IV } \\
\text { infusion after } \\
\text { dilution }\end{array}$ & $6 \mathrm{mg} / \mathrm{ml}$ & October, 2012 & $\begin{array}{l}\text { February, } \\
2026\end{array}$ & {$[32-33]$} \\
\hline $\begin{array}{l}\text { Paclitaxel (Abraxane)- } \\
\text { bound to albumin }\end{array}$ & NSCLC & $\begin{array}{l}\text { Powder for IV } \\
\text { infusion after } \\
\text { reconstituti-on, } \\
\text { first-line treatment } \\
\text { of locally advanced } \\
\text { or metastatic non- } \\
\text { small cell lung } \\
\text { cancer, in } \\
\text { combination with } \\
\text { carboplatin }\end{array}$ & $100 \mathrm{mg} /$ vial & October, 2012 & $\begin{array}{l}\text { December, } \\
2023\end{array}$ & [34] \\
\hline Vinorelbine (Navelbine) & NSCLC at stage III, & $\begin{array}{l}\text { Solution for IV } \\
\text { injection after } \\
\text { dilution }\end{array}$ & $10 \mathrm{mg} / \mathrm{ml}$ & December, 1994 & $\begin{array}{l}\text { February, } \\
2003\end{array}$ & [35] \\
\hline \multicolumn{7}{|c|}{ HUMAN EGFR INHIBITOR } \\
\hline Necitumumab (Portrazza) & $\begin{array}{ll}\text { Metastatic } & \text { squamous } \\
\text { NSCLC } & \end{array}$ & $\begin{array}{l}\text { solution for IV } \\
\text { infusion after } \\
\text { dilution }\end{array}$ & $\begin{array}{lll}800 & \mathrm{mg} / & 50 \\
\mathrm{ml} & & \end{array}$ & November, 2015 & 2025 & [36] \\
\hline \multicolumn{7}{|l|}{ Kinase inhibitors } \\
\hline Afatinib (Gilotrif) & $\begin{array}{l}\text { Metastatic squamous } \\
\text { NSCLC with EGFR } \\
\text { mutation at stage IV }\end{array}$ & Tablets & $\begin{array}{ll}20 & \mathrm{mg}, \quad 30 \\
\mathrm{mg}, & 40 \mathrm{mg}\end{array}$ & July, 2013 & $\begin{array}{l}\text { October, } \\
2029\end{array}$ & [37] \\
\hline Alectinib (Alecensa) & $\begin{array}{l}\text { ALK+ and Metastatic } \\
\text { squamous NSCLC }\end{array}$ & Capsules & $150 \mathrm{mg}$ & December,2015 & May, 2031 & [38] \\
\hline
\end{tabular}


Neha Kumari et al; Saudi J Med Pharm Sci, March., 2020; 6(3): 246-264

\begin{tabular}{|c|c|c|c|c|c|c|}
\hline Brigatinib (Alunbrig) & $\begin{array}{l}\text { Metastatic squamous } \\
\text { NSCLC }\end{array}$ & Tablets & $\begin{array}{l}30 \quad \mathrm{mg}, \quad 90 \\
\mathrm{mg}, \quad 180 \mathrm{mg}\end{array}$ & April, 2017 & May, 2029 & [39-40] \\
\hline Ceritinib (Zykadia) & $\begin{array}{l}\text { Metastatic squamous } \\
\text { NSCLC at stage IV }\end{array}$ & Hard gel capsules & $150 \mathrm{mg}$ & April, 2014 & $\begin{array}{l}\text { November,2 } \\
027\end{array}$ & [41] \\
\hline Crizotinib (Xalkori) & $\begin{array}{l}\mathrm{ALK}^{+} \text {NSCLC at stage } \\
\text { IV }\end{array}$ & Capsules & $\begin{array}{l}200 \mathrm{mg}, 250 \\
\mathrm{mg}\end{array}$ & August, 2011 & $\begin{array}{l}\text { November, } \\
2026\end{array}$ & {$[42-43]$} \\
\hline Dacomitinib (Vizimpro) & $\begin{array}{ll}\text { Metastatic } & \text { squamous } \\
\text { NSCLC } & \end{array}$ & Tablets & $\begin{array}{l}15 \mathrm{mg}, \quad 30 \\
\mathrm{mg}, \quad 45 \mathrm{mg}\end{array}$ & September, 2018 & * & [44] \\
\hline Erlotinib (Tarcev) & $\begin{array}{l}\text { Treatment of locally } \\
\text { advanced or metastatic } \\
\text { NSCLC Stage III and } \\
\text { IV after failure of at } \\
\text { least one prior } \\
\text { chemotherapy regimen }\end{array}$ & Tablets & $\begin{array}{l}25 \mathrm{mg}, \quad 100 \\
\mathrm{mg}, \quad 150 \mathrm{mg}\end{array}$ & November, 2004 & $\begin{array}{l}\text { November, } \\
2020\end{array}$ & {$[45-46]$} \\
\hline Gefitinib (Iressa) & $\begin{array}{l}2^{\text {nd }} \text { line treatment of } \\
\text { NSCLC }\end{array}$ & Tablets & $250 \mathrm{mg}$ & May, 2003 & May, 2017 & {$[47-48]$} \\
\hline Lorlatinib (Lorbrena) & $\begin{array}{ll}\text { Metastatic } & \text { squamous } \\
\text { NSCLC } & \end{array}$ & Tablets & 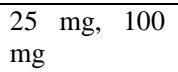 & $\begin{array}{ll}2 & \text { November } \\
2018 & \end{array}$ & * & [49] \\
\hline Osimertinib (tagrisso) & $\begin{array}{l}\text { EGFR T790M mutation } \\
\text { positive NSCLC }\end{array}$ & Tablets & $40 \mathrm{mg}, 80 \mathrm{mg}$ & November, 2015 & July, 2032 & {$[50-51]$} \\
\hline Trametinib (Mekinist) & $\begin{array}{l}\text { metastatic NSCLC with } \\
\text { BRAF V600E mutation }\end{array}$ & Tablets & $0.5 \mathrm{mg}, 2 \mathrm{mg}$ & May 2013 & $\begin{array}{l}\text { September, } \\
2025\end{array}$ & [52] \\
\hline \multicolumn{7}{|c|}{ PD-1/ PD-L1 BLOCKING ANTIBIODIES } \\
\hline \multirow[t]{2}{*}{ Atezolizumab (Tecentriq) } & $\begin{array}{l}\text { Extensive SCLC and } \\
\text { adenocarcinoma }\end{array}$ & \multirow{2}{*}{$\begin{array}{lrr}\begin{array}{l}\text { Solution } \\
\text { infusion }\end{array} & \text { for } & \text { IV } \\
\text { dilution } & & \end{array}$} & \multirow[t]{2}{*}{$60 \mathrm{mg} / \mathrm{ml}$} & March, 2019 & \multirow[t]{2}{*}{ May, 2026} & \multirow[t]{2}{*}{ [53] } \\
\hline & $\begin{array}{ll}\text { Metastatic } & \text { squamous } \\
\text { NSCLC } & \\
\end{array}$ & & & May, 2016 & & \\
\hline Durvalumab (Imfinzi) & Stage III NSCLC & $\begin{array}{l}\text { Solution for IV } \\
\text { infusion after } \\
\text { dilution }\end{array}$ & $50 \mathrm{mg} / \mathrm{ml}$ & May, 2017 & & [54] \\
\hline \multirow[t]{2}{*}{ Nivolumab (Opdivo) } & $\begin{array}{ll}\text { Metastatic squamous } \\
\text { NSCLC }\end{array}$ & \multirow{2}{*}{$\begin{array}{l}\text { Solution for IV } \\
\text { infusion after } \\
\text { dilution }\end{array}$} & \multirow[t]{2}{*}{$10 \mathrm{mg} / \mathrm{ml}$} & $\begin{array}{lr}\text { March, } & 2015 \\
\text { December, } 2014\end{array}$ & June, 2028 & \multirow[t]{2}{*}{ [55] } \\
\hline & $\begin{array}{l}\text { SCLC and at stage III or } \\
\text { IV of NSCLC }\end{array}$ & & & August, 2018 & May, 2026 & \\
\hline \multirow[t]{5}{*}{ Pembrolizumab (Keytruda) } & Cell carcinoma & \multirow{3}{*}{$\begin{array}{l}\text { Solution for IV } \\
\text { infusion after } \\
\text { dilution, }\end{array}$} & \multirow[t]{3}{*}{$50 \mathrm{mg} /$ vial } & December, 2018 & \multirow[t]{5}{*}{ March, 2032} & \multirow[t]{5}{*}{ [56-57] } \\
\hline & Stage III NSCLC & & & April 2019 & & \\
\hline & Metastatic SCLC & & & June, 2019 & & \\
\hline & Adenocar-cinoma & \multirow{2}{*}{$\begin{array}{l}\text { powder for IV } \\
\text { infusion after } \\
\text { reconstitution }\end{array}$} & \multirow[t]{2}{*}{$25 \mathrm{mg} / \mathrm{ml}$} & October, 2015 & & \\
\hline & Advance NSCLC & & & September, 2018 & & \\
\hline \multicolumn{7}{|c|}{ PHOTOSENSITIZING AGENT } \\
\hline Profimer (photofrin) & $\begin{array}{l}\text { Microinvasive } \\
\text { endobronchial NSCLC }\end{array}$ & $\begin{array}{l}\text { Powder for IV } \\
\text { injection after } \\
\text { reconstitution }\end{array}$ & $75 \mathrm{mg}$ & January 1998 & $*$ & [55] \\
\hline
\end{tabular}

\section{Radiotherapy}

Radiotherapy is used to deliver high energy Xrays/ionizing radiation i.e. Radium (228Ra), Iridium (192Ir), Phosphorous (32p), and Cobalt (60Co) that destroys DNA of cancer cells or shrink the tumor cells. It is especially used as primary treatment for NSCLC; before surgery it is used to shrink the tumor, after surgery it is used to remove remaining cancer cells in the treated area. It is also in used different cancer treatments that have spreaded to the brain and other parts of the body [58]. A delivery technique in radiotherapy includes external beam technique (EBT), conformal radiation therapy or Intensity-modulated radiation therapy (MRT), and branchytherapy or localized therapy (BLT). EBT is an intervention technique used for lung cancer treatment in which a beam of very few highly focused doses or fractionated radiation therapy is used directly at the site of the tumor [59]. MRT is comparatively new technique that uses 3D image of tumor cell CT scanner; it serves as the target for a high dose radiation beam. BLT is an after surgery procedure in which radiation is directly delivered at the site of obstruction through the plastic tube which is temporarily inserted into the airway [60].

\section{Radiotherapy and Microwave Ablation (MWA) of Lung Tumor}

Radiofrequency ablation (RFA) for lung tumors was first introduced in 2000 by Dupuy et al. [61]. It is an invasive treatment that uses image guidance technique to insert a needle containing multiple electrodes through the skin into the specific site of the tumor. Due to high frequency sinusoidal 
(electrical) currents are passed through the electrode to ground pads (placed on the body) which create focal heat that destroys the cancer cells surrounding the electrode (thermal destruction of cells and coagulation necrosis). MWA is the minimally invasive treatment that uses microwaves heat which destroys the tumor and also used for the guidance of needle placement in the tumor. MWA is used for the treatment of lung cancer whereas radiofrequency ablation may be limited by the accelerated lung's low electrical conductivity and poor thermal conduction [19].

\section{Stereotactic Ablative Body Radiotherapy (SABRT)}

SABRT is an advancement of an external beam of radiation therapy; high dose radiation is directly delivered to extracranial target within the body either as single dose or as a small fraction [62].This technique of treatment is widely used for inoperable stage I NSCLC and it improves local control or prolongs overall survival without an increase in major toxicity as compared to standard radiotherapy. Radiotherapy represents a safer and potentially curative option for stage I NSCLC in many patients who have smoking-related cardiac or respiratory comorbidities that make them unfit for operation [63].

\section{Supportive and Palliative Care (SPC)}

SPC also plays a vital role in the management of lung cancer that improves the quality of lung cancer patients. Temel and co researchers studied and analyzed the effect of early specialised palliative care support as compared to standard care in ambulatory patients with metastatic NSCLC referred to the medical oncology outpatient department [64] and found a significant difference in patient survival [65]. SPC includes medication to manage dyspnoea in patients with lung cancer, which includes use of systemic opioids (dose 10 to $30 \mathrm{mg} / \mathrm{ml}$ ) [66, 67], sustained release morphine [68], frusemide nebulised (dose of $40 \mathrm{mg} / 4 \mathrm{ml}$ ) to support chronic refractory breathlessness [69, 70]. It further includes non-pharmacological management of dyspnoea in lung cancer to reduce anxiety and distress $[71,72]$, and interventions to control psychological distress and unmet needs in lung cancer patients nurseled care in gradually increasing muscle relaxation combined with education on self-management of symptoms at the beginning and middle of radiotherapy [73], coping skills training for care givers also showed improvements in patient- and care giver-reported outcomes, including depression and self-efficacy over time [74]. An overarching specialist approach to palliative care delivery (by Quill and Abernathy and supported within the 2017 ASCO guidelines) introduced different types of potential models which are; concurrent care model that involves interdisciplinary palliative care team and triggered integration model which involves the oncology care team backed by the palliative care team. Concurrent and triggered integration models are hybrid of the models [75].

\section{Immunotherapy}

Immunotherapy is one of the most preferred treatments for lung cancer especially in the advanced metastatic stage of NSCLC because it can change or even enhance the survival rate of cancer patients. The significance of immune system lies in its potential to protect from attacking normal cells in body. For this purpose the proteins i.e. checkpoints on normal cells are required to be turned on/off to trigger/start the immune response. Two immune checkpoint inhibitor pathways are programmed cell death protein 1 (PD1)/Programmed death-ligand 1 (PD-L1) and cytotoxic T-lymphocyte-associated antigen-4 (CTLA-4). Immunotherapy of cancer works against tumor cells by repairing and enhancing the immune system which controls the killing of the tumor cells. The very firsttime immune phenomenon was discovered by Coley et al., 1893 [76-77]. An immunological checkpoint inhibitor severs as an immune blocker that prevents the release of tumors, and also induces the re-activation of $\mathrm{T}$ cells for the immune response to the tumor effect, thereby achieving an anti-tumor role as a new weapon against tumors. The prevalent mechanism by which lung cancer cells get away from the host's immunological response is through the expression of PD-L1, also called B7-H1 or CD274 [78]. PD-1 is an immune-regulatory receptor present on the surface of activated $\mathrm{T}$ cells. The PD-1 and PD-L1 interaction inhibits $\mathrm{T}$ cell responses leading to apoptosis of tumorspecific $\mathrm{T}$ cells and thus promotes differentiation of CD4+ T cells into regulatory $\mathrm{T}$ cells, and further avoids tumor cell resistance [79]. Immunotherapy can have a major role in cancer management either as a monotherapy or in the combination of standard treatment. However, the biggest threat is to ensure the maximum durable response with the minimum toxicity. There are three stages of cancer immune editing theory which involves elimination/ immune surveillance, equilibrium, and escape. Tumor cells (less immunogenic) are successfully destroyed by the host's immunity; this is called the elimination stage and reaches to equilibrium stage. In this stage, the immune system fails to completely abolish all cancer cells, but it can effectively manage further tumor growth. In the escape stage, the tumor outgrowth is out of immune control, as the cancer cells that have escaped continue to reproduce [80]. The cancer cells co-opt specific pathways of the immune system, especially against $\mathrm{T}$ cells targeting specific tumor antigens, leading to tumor resistance. However, as numbers of checkpoints are developed by ligandreceptor interactions, they can be easily blocked by antibodies or regulated by engineered ligands or receptors [81]. Two of the most encouraging approaches for blockade of immune checkpoints are through checkpoint inhibitor that includes cytotoxic T-lymphocyte-associated antigen-4 (CTLA-4) and PD1 inhibitors as well as vaccine 
Table 3- Summary of immunotherapy vaccines

\begin{tabular}{|c|c|c|c|}
\hline \\
\hline Vaccines & Immunological responses & Stages & Reference \\
\hline \multicolumn{4}{|l|}{ ANTIGEN- SPECIFIC VACCINES } \\
\hline $\begin{array}{l}\text { Mucin 1: A Cell Surface-Associated Antigen } \\
\text { (type 1 transmemberane proteins) L-BLP25 } \\
\text { (BLP25) Stimuvax, Biomira, Alberta, CA }\end{array}$ & $\begin{array}{l}\text { Extracellular core peptide of } \\
\text { MUC1 }\end{array}$ & $\begin{array}{l}\text { Stage III NSCLC after } \\
\text { treatment }\end{array}$ & {$[60,83-85]$} \\
\hline $\begin{array}{l}\text { GD3 (cell surface ganglioside antigen) } \\
\text { Anti-idiotype Antibody Bec2Plus, BCG Vaccine }\end{array}$ & Surface of cell & $\begin{array}{lr}\begin{array}{l}\text { Phase } 3 \quad \text { SCLC } \\
\text { chemotherapy }\end{array} & \text { after } \\
\text { radiotherapy } & \text { and } \\
\end{array}$ & {$[83,86-87]$} \\
\hline $\begin{array}{l}\text { Neu-Glycosylated Gangliosides } \\
\text { 1E10 Antiidiotype }\end{array}$ & Cell surface & $\begin{array}{l}\text { Phase } 1 \text { SCLC and stage } \\
\text { IIIB/IV NSCLC }\end{array}$ & {$[83,88-89]$} \\
\hline $\begin{array}{l}\text { Toll-like Receptor } 9 \\
\text { Vaccine PF-3512676 }\end{array}$ & $\begin{array}{l}\text { TLR9 is expressed on B and T } \\
\text { lymphocytes, plasmacytoid } \\
\text { cells, and dendritic cells }\end{array}$ & Stage IIIB/IV NSCLC & {$[83,90-91]$} \\
\hline $\begin{array}{l}\text { Melanoma-Associated Antigen A3 } \\
\text { Immunotherapeutic }\end{array}$ & $\begin{array}{l}\text { Tumor-specific antigen that is } \\
\text { not expressed on normal cells. }\end{array}$ & stage 1B to II NSCLC & {$[83,92-93]$} \\
\hline $\begin{array}{l}\text { Nine class I peptides (from CEA, p53, HER- } \\
\text { 2/neu, MAGE-2 and -3) with PADRE }\end{array}$ & CTL responses & IIIB-IV or recurrent & [94] \\
\hline $\begin{array}{l}\text { Modified Ankara virus containing MUC-1 and IL- } \\
2\end{array}$ & CTL responses & IIIB-IV & [95] \\
\hline $\begin{array}{l}\text { Optimized class I hTERT peptide p572Y and } \\
\text { native peptide p572 }\end{array}$ & CTL responses & III-IV & [96] \\
\hline $\begin{array}{l}\text { Immature DCs pulsed with apoptotic bodies from } \\
\text { NSCLC cell line }\end{array}$ & CTL responses & I-IIIB & [97] \\
\hline $\begin{array}{l}\text { Seven ras peptides encompassing predicted } \\
\text { mutations of codon } 12\end{array}$ & DTH responses & I or IV & [98] \\
\hline $\begin{array}{l}\text { hTERT class I peptide p611 and class II peptide } \\
\text { p540 with GM-CSF }\end{array}$ & T-cell proliferation & IIB-IV & [99] \\
\hline $\begin{array}{l}L 523 S \text { gene immunized in a plasmid followed by } \\
\text { a viral vector }\end{array}$ & Humoral responses & IB-IIB & {$[100]$} \\
\hline $\begin{array}{lcccc}\begin{array}{l}\text { Autologous tumor cells } \\
\text { transfected with GM-CSF }\end{array} & \text { with } & \text { K562 } & \text { cells } \\
\end{array}$ & DTH/humoral responses & III-IV & {$[101]$} \\
\hline $\begin{array}{l}\text { Dexosomes pulsed with MAGE-A3, -A4, -A10 } \\
\text { and -3DPO4 peptides }\end{array}$ & DTH responses & IIIB-IV & [102] \\
\hline Class I WT1 peptide p235 & CTL/DTH responses & IV & [103] \\
\hline $\begin{array}{l}\text { SART-1, }-2 \text { and }-3, \text { CypB, Lck, and ART-1 and -4 } \\
\text { peptides }\end{array}$ & CTL/DTH responses & IV or recurrent & [104] \\
\hline $\begin{array}{l}\text { B7.1 and HLA A1- or A2-transfected allogenic } \\
\text { NSCLC cell line }\end{array}$ & CTL responses & IIIB-IV & [105] \\
\hline \multicolumn{4}{|l|}{ TUMOR CELL VACCINES } \\
\hline $\begin{array}{l}\text { Granulocyte-Macrophage Colony-Stimulating } \\
\text { Factor-Transduced Allogeneic Cancer Cellular } \\
\text { Immunotherapy }\end{array}$ & APCs to the site of vaccination & Stage I/II NSCLC & $\begin{array}{l}{[83,106-} \\
107]\end{array}$ \\
\hline $\begin{array}{l}\text { Transforming Growth Factor__2 Antisense Gene- } \\
\text { Modified Allogeneic Tumor Cell Vaccine: }\end{array}$ & $\begin{array}{l}\text { Antisense oligonucleotide to } \\
\text { transforming growth factor- } 2 \\
\text { (TGF-2). }\end{array}$ & Stage II -IV NSCLC & {$[83,108]$} \\
\hline
\end{tabular}

\section{Immune Resistance and Checkpoint Inhibition}

CTLA4 (homologous to T cells co-stimulatory protein) is a member of the immunoglobulin family and is expressed by activated $\mathrm{T}$ cells, which delivers an inhibitory signal to $\mathrm{T}$ cells. The combination of the molecules binds to $\mathrm{CD} 80$ and CD86 with greater affinity, they are also known as B7-1 and B7-2, respectively, on antigen-presenting cells $[17,109]$. The FDA approved CTLA-4 inhibitors are Ipilimumab (fully humanized IgG1 monoclonal antibody) and Tremelimumab. The antitumor immune response is initiated by the recognition of the tumor antigens by $\mathrm{T}$ lymphocytes followed by the co-stimulatory binding of T-cell receptors (TCR) to peptide-major histocompatibility complex (MHC) on antigen presenting cells (APCs). CD28, a stimulatory molecule represented on $\mathrm{T}$ cells that promotes $\mathrm{T}$ cell activation by binding to CD80 and CD86 (B7-1 and B7-2) ligands on APCs [110]. PD-1 is a member of the extended CD28/CTLA-4 family of T cell, and it is also considered as an immune checkpoint receptor, expressed on activated $\mathrm{T}$ cells. Its ligands consist of 
PD-L1 and PD-L2, and mainly tumors are expressed by PD-L1 [111]. The combination of PD-1 and PD-L1, delivers the inhibitory signals that regulate reproduction and viability of CD4+ T and CD8+ T cells which have been shown in normal individuals in order to minimize the damage of the immune response to surrounding tissues and to prevent the development of autoimmune diseases [111-112]. In patients, it can reduce T-cell immunity killing the tumor local microenvironment leading to tumor immune escape and the progress of tumor growth [113]. A number of clinical studies [113115] have demonstrated that PD-1/PD-L1 inhibitors have excellent efficacy in advanced NSCLC. When PD1 binds to its ligands, PD-L1 and PD-L2 are expressed on APCs (Antigen presenting cells) on some normal and cancer cells and leads to T cell inactivation [116]. PD-L1 can interact with the B7 molecules, resulting in
T cells turning off [117]. PD-1-induced inhibition is a possible mechanism for adjusting immune resistance. Thus, anti-PD-1 antibodies can be generated to bind to the PD-1 receptor and blocking its interaction with PDL1/L2 and thus preventing T cell inactivation [118]. FDA approved drugs for PD-1/PDL-1 are Nivolumab [55] (a full human IgG4 monoclonal antibody against PD-1and first checkpoint inhibitor), Pembrolizumab [56-57] (human monoclonal antibody against PD-1 and its ligand PD-L1), Atezolizumab [53] (fully humanized, engineered monoclonal antibody of the $\mathrm{IgG1}$ isotype against PD-L1), and Durvalumab [54] (human

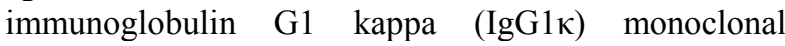
antibody against PD-L1 with PD-1 and CD80). Immune cycle of lung cancer is represented in figure 4 . Various checkpoints of lung cancer which are involved in treatment are summarized in Table 4.

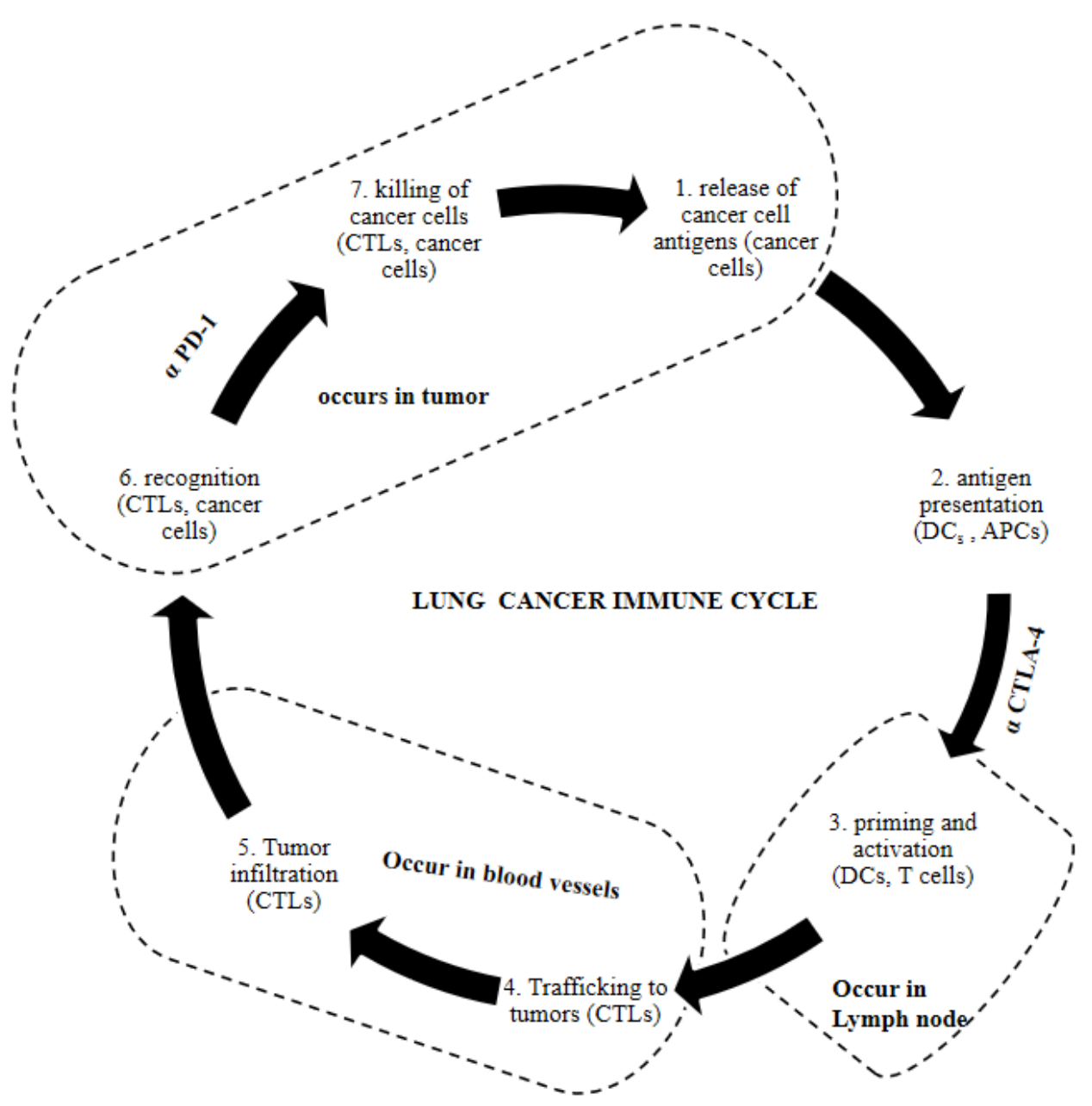

Fig-4: Lung cancer immune cycle 
Neha Kumari et al; Saudi J Med Pharm Sci, March., 2020; 6(3): 246-264

Table-4: Summary of Immunological checkpoints for treatment of target sites in lung cancer

\begin{tabular}{|c|c|c|c|c|}
\hline Immunoglobulin Antibiotics & Targeted site & $\begin{array}{l}\text { Activated } \\
\text { by }\end{array}$ & Action/Activity & Reference \\
\hline \multirow{2}{*}{$\begin{array}{l}\text { Lymphocyte activation gene-3 } \\
\text { (LAG-3) } \\
\text { Third Inhibitory Receptor }\end{array}$} & CTLA4 & \multirow{2}{*}{$\begin{array}{l}\text { T cells } \\
\text { NK cells } \\
\text { B cells } \\
\text { Plasma } \\
\text { cells }\end{array}$} & Reduce $\mathrm{T}_{\text {reg }}$ activity in-vivo & \multirow[t]{2}{*}[17,119]{} \\
\hline & PD1-PDL1 & & $\begin{array}{l}\text { Anti-tumor activity (advance } \\
\text { lung cancer) }\end{array}$ & \\
\hline \multirow{4}{*}{$\begin{array}{l}\text { T cells Ig and mucin domain-3 } \\
\text { (TIM-3) } \\
\text { Inhibitory Activity Of T Cells }\end{array}$} & CD4 + T helper 1 (Th1) & \multirow[t]{4}{*}{ Galectin -9} & Peripheral tolerance & \multirow[t]{4}{*}[17,120]{} \\
\hline & $\begin{array}{l}\text { CD8 + T cytotoxic } 1 \\
(\mathrm{Tc} 1) \text { and Th17 cells }\end{array}$ & & Loss of T cells in tumors & \\
\hline & CD4+ and CD8+ & & $\begin{array}{l}\text { Tumor infiltrating lymphocytes } \\
\text { in lung cancer patients }\end{array}$ & \\
\hline & CD4+ T cells & & $\begin{array}{l}\text { Lymph node metastasis and lung } \\
\text { cancer }\end{array}$ & \\
\hline $\begin{array}{lll}\text { Killer cell immunoglobulin } & \text { like } \\
\text { receptor (KIR) } & \text { (glycoproteins) } & \\
\end{array}$ & T CD8+ Cells & NK cells & Cytotoxic activity & {$[17,121]$} \\
\hline
\end{tabular}

\section{Targeted Therapies}

Target Cells with Anti- Angiogenesis Inhibitor

Anti-angiogenesis therapy is a developing field in lung cancer treatment. Vascular endothelial growth factor (VEGF) is playing a significant role in blocking tumor vascularization or it interferes with the activity of the growth factor receptors and molecular pathways that are triggered by the activation of this receptor. VEGF drugs would cause a reduction in blood vessel sprouting and the formation and moderate destruction of existing tumor vasculature. However, recent studies conclude that anti-angiogenesis drugs lead to normalization of the tumor vasculature (means normal phenotype of tumor cells) and also increase the delivery of oxygen and drugs to the tumor thus lifting the local hypoxia (which leads to selection of more aggressive tumor clones) and amplification of chemotherapeutic efficiency [106].

\section{Target Cells with Epidermal Growth Factor Receptor Inhibitors}

Epidermal growth factor receptor (EGFR) is one of the proteins (transmembrane growth factor receptor) which are present on the surface of the cell and it is responsible for the growth, survival, and proliferation of the cell. The huge amount of EGFR is present on the surface of tumor cells which causes unnecessary proliferation of cells. EFGR inhibitors are used to block the signals and growth of tumor cells [77]. It may further lead to shrinkage of tumor cells due to alteration in the EGFR gene and is termed as T790M mutation [107].

Tyrosine kinase inhibitors (TRI) are known to inhibit mutation of EFGR and its constitutive activation via reversible inhibition of the ATP-binding pocket in the EGFR kinase domain. The major mechanism behind this resistance is T790M mutation within the EFGR kinase domain. It also increases affinity for ATP, thus reducing inhibitor binding to the EGFR kinase domain while preserving catalytic activity [108].

\section{Target Cells with ALK (Anaplastic Lymphoma Kinase) Genes}

Translocation and functional impairment of the ALK genes is responsible for the mutation, proliferation and survival of lung cancer cells. Generally, it is a chromosomal rearrangement of genes in which EML4ALK product is formed due to the fusion between EML4 (echinoderm microtubule-associated protein-like 4) and ALK genes. This product is responsible for the constitutive activation of the kinase [38, 40]. Approximately, 3-4\% of NSCLC patients have this type of fusion gene product [90]. This rearrangement may produce abnormal ALK protein, which is also responsible for the unwanted growth of cells [122].

\section{Target Cells with Braf (V-Raf Murine Sarcoma Viral Oncogene Homolog B1)}

BRAF is a RAF serine/threonine protein kinase. Mutation of BRAF with RAF kinase activates the MAPK pathway, which causes uncontrolled growth and proliferation of the cells. Approximately 2-3\% of NSCLC cases are reported to be due to a mutation in BRAF. Valine 900 Glu (V900E) mutation within exons 15 kinase domain contributes to lung cancer (lung adenocarcinoma) [108].

\section{Anti Inflammatory Therapies}

It has been observed during clinical trials that long term use of aspirin, which is primarily used to prevent cardiovascular disease, also contributes in reducing the lung cancer death rate [125]. A large randomized trial of canakinumab, an antibody targeting IL-1 $\beta$ in patients with atherosclerosis, showed that patients receiving canakinumab had a statistically significant reduction in new lung cancer incidence and mortality [123]. Two recent studies depicted the future therapeutic potential of the NF- $\kappa \mathrm{B}$-mediated inflammatory pathway in lung cancer. The presence of oncogenic Ras, inflammatory stimuli depicts the cox-1, cox-2 involvement of NF- $\mathrm{BB}$ that further augments Ras activity and enzyme IKK2 and Timp1 which activates 
the inflammatory response of the body may effectively treat certain lung cancers [126].
The list of drugs used in targeted therapy along with their FDA status is discussed in Table 5.

Table-5: Summarizes drugs used in target therapy along with their FDA status

\begin{tabular}{|c|c|c|c|c|c|}
\hline Drug & Drug type & Effect & Combine with & $\begin{array}{l}\text { Clinical } \\
\text { trials }\end{array}$ & Reference \\
\hline Bevacizumab & $\begin{array}{ll}\text { Monoclonal } & \text { antibody } \\
\text { against VEGF } & \end{array}$ & $\begin{array}{l}\text { Improved PFS and } \\
\text { RR in patients with } \\
\text { non-squamous } \\
\text { NSCLC }\end{array}$ & $\begin{array}{l}\text { FDA approval first-line } \\
\text { treatment along } \\
\text { platinum-based with } \\
\text { carboplatin and paclitaxel }\end{array}$ & Phase III & $\begin{array}{l}{[106,123-} \\
124]\end{array}$ \\
\hline $\begin{array}{l}\text { Ramucirumab } \\
\text { (Cyramza) }\end{array}$ & $\begin{array}{l}\text { Monoclonal antibody } \\
\text { against VEGFR }\end{array}$ & $\begin{array}{l}\text { Improved PFS and } \\
\text { RR in patients with } \\
\text { non-squamous } \\
\text { NSCLC }\end{array}$ & $\begin{array}{l}\text { FDA approval second-line } \\
\text { treatment along } \\
\text { platinum-based drugs with } \\
\text { carboplatin and paclitaxel }\end{array}$ & Phase IV & [28] \\
\hline Aflibercept & $\begin{array}{l}\text { Decoy receptor fusion } \\
\text { protein, binding VEGF- } \\
\text { A, VEGF-B, and } \\
\text { Placental growth factor }\end{array}$ & $\begin{array}{l}\text { Improved PFS and } \\
\text { RR in patients with } \\
\text { NSCLC }\end{array}$ & Combination with docetaxel & Phase III & {$[106,124]$} \\
\hline Axitinib & $\begin{array}{l}\text { MT-TKI, } \\
\text { VEGFR-1, } 2 \text { against } \\
\text { PDGFR and c-kit }\end{array}$ & $\begin{array}{l}\text { Promising phase II } \\
\text { results in patients } \\
\text { with NSCLC }\end{array}$ & Combination with docetaxel & Phase II & {$[106]$} \\
\hline Cediranib & $\begin{array}{l}\text { MT-TKI, } \\
\text { VEGFR-1, } 2 \text { against } \\
\text { PDGFR and c-kit }\end{array}$ & $\begin{array}{l}\text { Significant activity } \\
\text { and toxicity in } \\
\text { patients with NSCLC }\end{array}$ & Combination with docetaxel & $\begin{array}{l}\text { Phase III } \\
\text { advance } \\
\text { NSCLC }\end{array}$ & $\begin{array}{l}{[106,123-} \\
124]\end{array}$ \\
\hline Motesanib & $\begin{array}{l}\text { MT-TKI, } \\
\text { VEGFR-1, 2 against } \\
\text { PDGFR, c-kit and RET }\end{array}$ & $\begin{array}{l}\text { Improved PFS in a } \\
\text { phase II trial in the } \\
\text { setting of NSCLC }\end{array}$ & $\begin{array}{l}\text { Combination with carboplatin } \\
\text { and paclitaxel }\end{array}$ & Phase III & $\begin{array}{l}{[106,123-} \\
124]\end{array}$ \\
\hline Sorafenib & $\begin{array}{l}\text { MT-TKI, against } \\
\text { VEGFR-2 and 3, } \\
\text { PDGFR, B-Raf and C- } \\
\text { Raf }\end{array}$ & $\begin{array}{l}\text { Increased PFS in } \\
\text { patients with NSCLC }\end{array}$ & $\begin{array}{l}\text { PFS and OS negative when } \\
\text { giving in combination with } \\
\text { chemotherapy Pending }\end{array}$ & Phase III & $\begin{array}{l}{[106,123-} \\
124]\end{array}$ \\
\hline Sunitinib & $\begin{array}{l}\text { MT-TKI, against } \\
\text { VEGFRs, PDGFR, c-kit, } \\
\text { flt3, RET and CSF-1R }\end{array}$ & $\begin{array}{l}\text { Increased PFS and } \\
\text { RR }\end{array}$ & $\begin{array}{l}\text { combination with erlotinib, in } \\
\text { patients with NSCLC }\end{array}$ & Phase III & {$[106,124]$} \\
\hline Endostatin & $\begin{array}{l}\text { Natural inhibitor of } \\
\text { angiogenesis } \\
\text { Targets bFGF, VEGF }\end{array}$ & $\begin{array}{lll}\text { Increased } & \text { PFS and } \\
\text { RR } & & \end{array}$ & $\begin{array}{lr}\text { combination } & \text { with } \\
\text { chemotherapy } & \text { and } \\
\text { chemoradiation in NSCLC }\end{array}$ & Phase III & 123 \\
\hline Pazopanib & $\begin{array}{l}\text { Targets c-KIT, FGFR, } \\
\text { PDGFR and VEGFR }\end{array}$ & $\begin{array}{l}\text { Combination with } \\
\text { Docetaxel }\end{array}$ & $\begin{array}{l}\text { NSCLC patients who have } \\
\text { received first- line therapy } \\
\text { (NCT01208064) } \\
\text { Refractory small cell lung } \\
\text { cancer } \\
\text { (NCT01253369) }\end{array}$ & $\begin{array}{l}\text { Phase II/III } \\
\text { Phase II }\end{array}$ & 120 \\
\hline Vandetanib & $\begin{array}{l}\text { MT-TKI, against } \\
\text { VEGFR, EGFR and RET }\end{array}$ & $\begin{array}{l}\text { Small increase in PFS } \\
\text { in patients with } \\
\text { NSCLC }\end{array}$ & Combination with Docetaxel & Phase III & $\begin{array}{l}{[106,123-} \\
124]\end{array}$ \\
\hline Nintedanib & VEGFR, FGFR, PDGFR & $\begin{array}{l}\text { Increased PFS and } \\
\text { RR }\end{array}$ & Combination with Docetaxel & Phase III & 123 \\
\hline \multicolumn{6}{|c|}{$\begin{array}{l}\text { NSCLC: non small cell lung cancer; SCLC: small cell lung cancer; VEGF: Vascular endothelial growth factor; EGFR: epiderma } \\
\text { growth factor receptor; TRI: tyrosine kinase inhibitors; ALK: anaplastic lymphoma kinase; BRAF- V-RAF murine sarcoma vira } \\
\text { oncogene homolog b1; PFS: Progrssive free survival; RR- respiratory rate; PDGF-R: platelet derived growth factor receptor, CSF-1R } \\
\text { colony simulating factor } 1 \text { receptor; FGFR: fibroblast growth receptor. }\end{array}$} \\
\hline
\end{tabular}

\section{CONCLUSION}

One of the culprits for lung cancer is smoking. However, many patients continue to smoke even after diagnosis which places them at higher risk of treatment toxicity and cancer recurrence. The patients who continue to smoke must be offered interventions to help them quit. Lung cancer patients and their care givers need psychological support so that they are able to cope with the consequences of diagnosis and treatment. In patients with metastatic disease, palliative radiotherapy is effective for the management of pain and coughing up of blood or blood-stained mucus from the bronchi, larynx, trachea, or lungs. Patients at advanced stage should be provided palliative care. Early palliative care improves outcomes including survival of the patient. Chemotherapy along with surgery and radiation therapy is used commonly for the management of lung cancer. 


\section{Future perspective}

In the past decades, chemotherapeutic drugs are widely used either in a single form or in combination and also associated with other therapies such as surgery, radiotherapy to improve the condition of the patient. Palliative and supportive cares are given to a patient also plays an important role in the recovering of tumor patients. But, each therapy has its own limitations such as chemotherapeutic agent is nonspecifically distributed throughout the body where they affect both cancerous and non-cancerous cells, which cause various side effects such as rash, alopecia, severe liver, and kidney function decline, cardio-toxicity, bone marrow suppression and also quality of patient's life. In the current scenario, enormous advancement in the development and application of bioinformatics and nanotechnology has been developed for the detection, diagnosis, and therapy of cancer. The Development of nanotechnology has revolutionized the treatment of lung cancer to a very great extent and also formulates target specific formulation with a high affinity for cancer treatment. It also helps to overcome the drawbacks and lacking specificity in conventional therapies that are not possible with other types of therapeutic drugs, and have shown a bright future as a new generation of cancer therapeutics.

\section{Financial and competing interest's disclosure}

The authors have no relevant affiliations or financial involvement with organization or entity with a financial interest in or financial conflict with the subject matter or material discussed in the manuscript. This includes employment, consultancies, honoraria, stock ownership or options expert testimony, rants or patents received or pending or royalties.

No writing assistance was utilized in the production of this manuscript.

\section{REFERENCES}

1. Sivarajakumar, R., Mallukaraj, D., Kadavakollu, M., Neelakandan, N., Chandran, S., Bhojaraj, S \& Satyanarayana, V. V. (2018). Nanoparticles for the Treatment of Lung Cancers. Journal of Young Pharmacists, 10(3), 276-81.

2. Thakur, C. (2019). An Overview, Current Challenges of Drug Resistance, and Targeting Metastasis Associated With Lung Cancer. In Nanotechnology-Based Targeted Drug Delivery Systems for Lung Cancer (pp. 21-38). Academic Press.

3. lungcancer.org (lungcancer101)

https://www.lungcancer.org/find_information/publ ications/163-lung_cancer_101/268

4. Travis, W. D., Brambilla, E., Nicholson, A. G., Yatabe, Y., Austin, J. H., Beasley, M. B., ... \& Geisinger, K. (2015). The 2015 World Health Organization classification of lung tumors: impact of genetic, clinical and radiologic advances since the 2004 classification. Journal of thoracic oncology, 10(9), 1243-1260.

5. Zheng, M. (2016). Classification and pathology of lung cancer. Surgical Oncology Clinics, 25(3), 447-468.

6. Garg, P. K., Sharma, G., Rai, S., \& Jakhetiya, A. (2019). Primary salivary gland-type tumors of the lung: A systematic review and pooled analysis. Lung India: official organ of Indian Chest Society, 36(2), 118.

7. Saraya, T., Fujiwara, M., Kimura, H., Takei, H., \& Takizawa, H. (2019). A 17- year- old woman with a solitary, mixed squamous cell and glandular papilloma of the bronchus. Respirology case reports, 7(2), e00393.

8. Hashimoto, H., Tsugeno, Y., Sugita, K., \& Inamura, K. (2019). Mesenchymal tumors of the lung: diagnostic pathology, molecular pathogenesis, and identified biomarkers. Journal of thoracic disease, 11(Suppl 1), S9.

9. Jung, C. Y., \& Kwon, K. Y. (2012). A case of synchronous lung adenocarcinoma and extranodal marginal zone B-cell lymphoma of mucosaassociated lymphoid tissue (MALT) type. Tuberculosis and respiratory diseases, 73(1), 61-66.

10. Zhu, Z., Liu, W., Mamlouk, O., O’Donnell, J. E., Sen, D., \& Avezbakiyev, B. (2017). Primary pulmonary diffuse large B cell non-Hodgkin's lymphoma: a case report and literature review. The American journal of case reports, 18, 286.

11. Ankita, G., \& Shashi, D. (2016). Pulmonary Lymphomatoid granulomatosis-a case report with review of literature. Indian journal of surgical oncology, 7(4), 484-487.

12. Zhang, Y., Bi, L., Qiu, Y., Zhao, T., Cao, M., Ding, J. \& Cai, H. (2018). Primary pulmonary intravascular large B-cell lymphoma: A report of three cases and literature review. Oncology letters, 15(3), 3610-3613.

13. Tazi, A. (2006). Erişkin akciğer Langerhans hücreli histiyositozisi. European Respiratory Journal, 27, 1272-1285.

14. Nor, F., Anamali, S., Timmons, S., Ahsan, M. S., Cuellar, J. P. C., Steward-Tharp, S., \& Handoo, N. (2019). Primary xanthoma of the mandible: a case report of a rare entity. Oral Surgery, Oral Medicine, Oral Pathology and Oral Radiology, 128(1), e69.

15. Ishibashi, F., Moriya, Y., Tamura, H., Matsui, Y., \& Iizasa, T. (2015). Differential diagnosis of primary intrapulmonary thymoma: a report of two cases. Surgical case reports, 1(1), 1-6.

16. Mittal, V., El Rayes, T., Narula, N., McGraw, T. E., Altorki, N. K., \& Barcellos-Hoff, M. H. (2016). The microenvironment of lung cancer and therapeutic implications. In Lung Cancer and Personalized Medicine: Novel Therapies and 
Clinical Management (pp. 75-110). Springer, Cham.

17. Qin, H., Wang, F., Liu, H., Zeng, Z., Wang, S., Pan, X., \& Gao, H. (2018). New advances in immunotherapy for non-small cell lung cancer. American journal of translational research, 10(8), 2234.

18. Cancercenter (lung cancer) https://www.cancercenter.com/cancer-types/lungcancer/treatments

19. Lung cancer therapy (therapy developments)

https://www.radiologyinfo.org/en/info.cfm?pg=lu ng-cancertherapy\#therapy- developments

20. Rani, D., Somasundaram, V. H., Nair, S., \& Koyakutty, M. (2012). Advances in cancer nanomedicine. Journal of the Indian Institute of Science, 92(2), 187-218.

21. Ruiz-Ceja, K. A., \& Chirino, Y. I. (2017). Current FDA-approved treatments for non-small cell lung cancer and potential biomarkers for its detection. Biomedicine \& Pharmacotherapy, 90, 24-37.

22. Ogawa, A., Kondo, K., Takei, H., Fujisawa, D., Ohe, Y., \& Akechi, T. (2018). Decision- Making Capacity for Chemotherapy and Associated Factors in Newly Diagnosed Patients with Lung Cancer. The oncologist, 23(4), 489.

23. Xia, Y., Tian, X., Wang, J., Qiao, D., Liu, X., Xiao, L., \& Wang, R. (2018). Treatment of metastatic non-small cell lung cancer with NY-ESO-1 specific TCR engineered-T cells in a phase I clinical trial: A case report. Oncology letters, 16(6), 6998-7007.

24. Burdett, S., Stewart, L., \& Rydzewska, L. (2007). Chemotherapy and surgery versus surgery alone in non- small cell lung cancer. Cochrane database of systematic reviews, (3).

25. Robinson, L. A., Ruckdeschel, J. C., Wagner Jr, H., \& Stevens, C. W. (2007). Treatment of nonsmall cell lung cancer-stage IIIA: ACCP evidencebased clinical practice guidelines. Chest, 132(3), 243S-265S.

26. Pisters, K. M., Evans, W. K., Azzoli, C. G., Kris, M. G., Smith, C. A., Desch, C. E., ... \& Gaspar, L. E. (2007). Cancer Care Ontario and American Society of Clinical Oncology adjuvant chemotherapy and adjuvant radiation therapy for stages I-IIIA resectable non-small-cell lung cancer guideline. Journal of clinical oncology, 25(34), 5506-5518.

27. Russo, A. E., Priolo, D., Antonelli, G., Libra, M., McCubrey, J. A., \& Ferrau, F. (2017). Bevacizumab in the treatment of NSCLC: patient selection and perspectives. Lung Cancer: Targets and Therapy, 8, 259.

28. Fala, L. (2015). Cyramza (Ramucirumab) Approved for the Treatment of Advanced Gastric Cancer and Metastatic Non-Small-Cell Lung
Cancer. American health \& drug benefits, 8(Spec Feature), 49.

29. Hayashi, H., Kurata, T., \& Nakagawa, K. (2011). Gemcitabine: efficacy in the treatment of advanced stage nonsquamous non-small cell lung cancer. Clinical Medicine Insights: Oncology, 5, CMO-S6252.

30. Hagner, N., \& Joerger, M. (2010). Cancer chemotherapy: targeting folic acid synthesis. Cancer management and research, 2, 293.

31. Laurie, S. A., \& Kris, M. G. (2000). Single-Agent Docetaxel (Taxotere $\AA$ ) in the Treatment of Advanced Non-Small-Cell Lung Cancer: Clinical Concepts and Commentary. Clinical lung cancer, 1, S5-S9.

32. Ojima, I., Lichtenthal, B., Lee, S., Wang, C., \& Wang, X. (2016). Taxane anticancer agents: a patent perspective. Expert opinion on therapeutic patents, 26(1), 1-20.

33. Sun, B., Straubinger, R. M., \& Lovell, J. F. (2018). Current taxane formulations and emerging cabazitaxel delivery systems. Nano Research, 11(10), 5193-5218.

34. US Food and drug association www.accessdata.fda.gov/drugsatfda_docs/nda/201 2/021660Orig1s031.pdf [accessed 11 October 2012]

35. Cazzaniga, M. E., Camerini, A., Addeo, R., Nolè, F., Munzone, E., Collovà, E. \& Saracchini, S. (2016). Metronomic oral vinorelbine in advanced breast cancer and non-small-cell lung cancer: current status and future development. Future oncology, 12(3), 373-387.

36. Thatcher, N., Hirsch, F. R., Luft, A. V., Szczesna, A., Ciuleanu, T. E., Dediu, M., \& Kazarnowicz, A. (2015). Necitumumab plus gemcitabine and cisplatin versus gemcitabine and cisplatin alone as first-line therapy in patients with stage IV squamous non-small-cell lung cancer (SQUIRE): an open-label, randomised, controlled phase 3 trial. The lancet oncology, 16(7), 763-774.

37. Deeks, E. D., \& Keating, G. M. (2018). Correction to: Afatinib in advanced NSCLC: a profile of its use. Drugs \& Therapy Perspectives, 34(4), 196196.

38. Peters, S., Camidge, D. R., Shaw, A. T., Gadgeel, S., Ahn, J. S., Kim, D. W., \& Zeaiter, A. (2017). Alectinib versus crizotinib in untreated ALKpositive non-small-cell lung cancer. New England Journal of Medicine, 377(9), 829-838.

39. Bedi, S., Khan, S. A., AbuKhader, M. M., Alam, P., Siddiqui, N. A., \& Husain, A. (2018). A comprehensive review on Brigatinib-A wonder drug for targeted cancer therapy in non-small cell lung cancer. Saudi Pharmaceutical Journal, 26(6), 755-763.

40. Quandt, D., Fiedler, E., Boettcher, D., Marsch, W. C., \& Seliger, B. (2011). B7-h4 expression in 
human melanoma: its association with patients' survival and antitumor immune response. Clinical cancer research, 17(10), 3100-3111.

41. Cooper, M. R., Chim, H., Chan, H., \& Durand, C. (2015). Ceritinib: a new tyrosine kinase inhibitor for non-small-cell lung cancer. Annals of Pharmacotherapy, 49(1), 107-112.

42. Timm, A., \& Kolesar, J. M. (2013). Crizotinib for the treatment of non-small-cell lung cancer. American journal of health-system pharmacy, 70(11), 943-947.

43. Sahu, A., Prabhash, K., Noronha, V., Joshi, A., \& Desai, S. (2013). Crizotinib: A comprehensive review. South Asian journal of cancer, 2(2), 91.

44. US food and drug association. https://www.fda.gov/drugs/drug-approvals-anddatabases/fda-approves-dacomitinib-metastaticnon-small-cell-lung-cancer-0 $\quad[27$ September 2018]

45. Rocha-Lima, C. M., \& Raez, L. E. (2009). Erlotinib (tarceva) for the treatment of non-smallcell lung cancer and pancreatic cancer. Pharmacy and Therapeutics, 34(10), 554.

46. Gridelli, C., Bareschino, M. A., Schettino, C., Rossi, A., Maione, P., \& Ciardiello, F. (2007). Erlotinib in non-small cell lung cancer treatment: current status and future development. The oncologist, 12(7), 840-849.

47. Nurwidya, F., Takahashi, F., \& Takahashi, K. (2016). Gefitinib in the treatment of nonsmall cell lung cancer with activating epidermal growth factor receptor mutation. Journal of natural science, biology, and medicine, 7(2), 119.

48. Araki, T., Yashima, H., Shimizu, K., Aomori, T., Hashita, T., Kaira, K., \& Yamamoto, K. (2012). Review of the treatment of non-small cell lung cancer with gefitinib. Clinical Medicine Insights: Oncology, 6, CMO-S7340.

49. Akamine, T., Toyokawa, G., Tagawa, T., Yamazaki, K., Seto, T., Takeo, S., \& Mori, M. (2019). Lorlatinib for the treatment of patients with non-small cell lung cancer. Drugs of today (Barcelona, Spain: 1998), 55(2), 107-116.

50. Chen, P., Chen, F., Lei, J., \& Zhou, B. (2018). curative effectiveness and safety of osimertinib in the treatment for non-small-cell lung cancer: a meta-analysis of the experimental evidence. Onco Targets and therapy, 11, 9033.

51. Scott, L. J. (2018). Osimertinib as first-line therapy in advanced NSCLC: a profile of its use. Drugs \& Therapy Perspectives, 34(8), 351357.

52. Dong, J., Li, B., Zhou, Q., Lin, D., \& Huang, D. (2019). Advances in targeted therapy and immunotherapy for non-small cell lung cancer based on accurate molecular typing. Frontiers in Pharmacology, 10, 230

53. Santini, F. C., \& Rudin, C. M. (2017). Atezolizumab for the treatment of non-small cell lung cancer. Expert review of clinical pharmacology, 10(9), 935-945.

54. Mezquita, L., \& Planchard, D. (2018). Durvalumab for the treatment of non-small cell lung cancer. Expert review of respiratory medicine, 12(8), 627-639.

55. Lim, J. S., \& Soo, R. A. (2016). Nivolumab in the treatment of metastatic squamous non-small cell lung cancer: a review of the evidence. Therapeutic advances in respiratory disease, 10(5), 444-454.

56. Peters, S., Kerr, K. M., \& Stahel, R. (2018). PD-1 blockade in advanced NSCLC: a focus on pembrolizumab. Cancer treatment reviews, 62, 39-49.

57. Ninomiya, K., \& Hotta, K. (2018). Pembrolizumab for the first-line treatment of nonsmall cell lung cancer. Expert opinion on biological therapy, 18(10), 1015-1021.

58. Shafirstein, G., Battoo, A., Harris, K., Baumann, H., Gollnick, S. O., Lindenmann, J., \& Nwogu, C. E. (2016). Photodynamic therapy of non-small cell lung cancer. Narrative review and future directions. Annals of the American Thoracic Society, 13(2), 265-275.

59. Baskar, R., Lee, K. A., Yeo, R., \& Yeoh, K. W. (2012). Cancer and radiation therapy: current advances and future directions. International journal of medical sciences, 9(3), 193.

60. Butts, C., Maksymiuk, A., Goss, G., Soulieres, D., Marshall, E., Cormier, Y., \& Falk, M. (2011). Updated survival analysis in patients with stage IIIB or IV non-small-cell lung cancer receiving BLP25 liposome vaccine (L-BLP25): phase IIB randomized, multicenter, open-label trial. Journal of cancer research and clinical oncology, 137(9), 1337-1342.

61. Dupuy, D. E., Zagoria, R. J., Akerley, W., MayoSmith, W. W., Kavanagh, P. V., \& Safran, H. (2000). Percutaneous radiofrequency ablation of malignancies in the lung. American Journal of Roentgenology, 174(1), 57-59.

62. Potters, L., Kavanagh, B., Galvin, J. M., Hevezi, J. M., Janjan, N. A., Larson, D. A., \& Welsh, J. S. (2010). American Society for Therapeutic Radiology and Oncology (ASTRO) and American College of Radiology (ACR) practice guideline for the performance of stereotactic body radiation therapy. International Journal of Radiation Oncology• Biology• Physics, 76(2), 326-332.

63. Ball, D., Mai, G. T., Vinod, S., Babington, S., Ruben, J., Kron, T., \& Elder, C. (2019). Stereotactic ablative radiotherapy versus standard radiotherapy in stage 1 non-small-cell lung cancer (TROG 09.02 CHISEL): a phase 3, open-label, randomised controlled trial. The Lancet Oncology, 20(4), 494-503.

64. Thomas, T. H., Jackson, V. A., Carlson, H., Rinaldi, S., Sousa, A., Hansen, A., \& Temel, J. S. (2019). Communication differences between 
oncologists and palliative care clinicians: a qualitative analysis of Early, Integrated Palliative care in patients with advanced cancer. Journal of palliative medicine, 22(1), 41-49.

65. Bakitas, M., Lyons, K. D., Hegel, M. T., Balan, S., Brokaw, F. C., Seville, J., \& Ahles, T. A. (2009). Effects of a palliative care intervention on clinical outcomes in patients with advanced cancer: the Project ENABLE II randomized controlled trial. Jama, 302(7), 741-749.

66. Wiseman, R., Rowett, D., Allcroft, P., Abernethy, A., \& Currow, D. (2013). Chronic refractory dyspnoea: $\quad$ Evidence based management. Australian family physician, 42(3), 137.

67. Hanania, N. A., \& O'Donnell, D. E. (2019). Activity-related dyspnea in chronic obstructive pulmonary disease: physical and psychological consequences, unmet needs, and future directions. International journal of chronic obstructive pulmonary disease, 14, 1127.

68. Currow, D. C., Quinn, S., Greene, A., Bull, J., Johnson, M. J., \& Abernethy, A. P. (2013). The longitudinal pattern of response when morphine is used to treat chronic refractory dyspnea. Journal of palliative medicine, 16(8), 881-886.

69. Boyden, J. Y., Connor, S. R., Otolorin, L., Nathan, S. D., Fine, P. G., Davis, M. S., \& Muir, J. C. (2015). Nebulized medications for the treatment of dyspnea: a literature review. Journal of aerosol medicine and pulmonary drug delivery, 28(1), 119.

70. Carone, L., Oxberry, S. G., Twycross, R., Charlesworth, S., Mihalyo, M., \& Wilcock, A. (2016). Furosemide. Journal of pain and symptom management, 52(1), 144-150.

71. Nava, S., Ferrer, M., Esquinas, A., Scala, R., Groff, P., Cosentini, R., \& Grassi, M. (2013). Palliative use of non-invasive ventilation in endof-life patients with solid tumours: a randomised feasibility trial. The lancet oncology, 14(3), 219227.

72. Rutkowska, A., Jastrzebski, D., Rutkowski, S., Żebrowska, A., Stanula, A., Szczegielniak, J. \& Casaburi, R. (2019). Exercise Training in Patients with Non-Small Cell Lung Cancer during InHospital Chemotherapy Treatment: a randomized controlled trial. Journal of cardiopulmonary rehabilitation and prevention, 39(2), 127.

73. Beasley, A., Bakitas, M. A., Edwards, R., \& Kavalieratos, D. (2019). Models of non-hospice palliative care: a review. Annals of palliative medicine, 8(Suppl 1), S15-S21.

74. Said, S. A., Bloo, R., \& van Dalen, P. (2018). A survey of participant's satisfaction of a nurse practitioner-led fast-track outpatient clinic for rhythm and conduction disorder. Asian Journal of Cardiology Research, 1-12.
75. Balboni, T. A., Hui, K. K. P., \& Kamal, A. H. (2018). Supportive care in lung cancer: improving value in the era of modern therapies. American Society of Clinical Oncology Educational Book, 38, 716-725.

76. Demaria, O., Cornen, S., Daëron, M., Morel, Y., Medzhitov, R., \& Vivier, E. (2019). Harnessing innate immunity in cancer therapy. Nature, 574(7776), 45-56.

77. Kim, E. Y., Kim, A., Lee, G., Lee, H., \& Chang, Y. S. (2018). Different mutational characteristics of the subsets of EGFR-tyrosine kinase inhibitor sensitizing mutation-positive lung adenocarcinoma. BMC cancer, 18(1), 1221.

78. Jiang, Y., Li, Y., \& Zhu, B. (2015). T-cell exhaustion in the tumor microenvironment. Cell death \& disease, 6(6), e1792.

79. Malhotra, J., Jabbour, S. K., \& Aisner, J. (2017). Current state of immunotherapy for non-small cell lung cancer. Translational lung cancer research, 6(2), 196.

80. Forde, P. M., Reiss, K. A., Zeidan, A. M., \& Brahmer, J. R. (2013). What lies within: novel strategies in immunotherapy for non-small cell lung cancer? The oncologist, 18(11), 1203.

81. Pardoll, D. M. (2012). The blockade of immune checkpoints in cancer immunotherapy. Nature Reviews Cancer, 12(4), 252-264.

82. Khanna, P., Blais, N., Gaudreau, P. O., \& Corrales-Rodriguez, L. (2017). Immunotherapy comes of age in lung cancer. Clinical lung cancer, 18(1), 13-22.

83. Shine Raju, R. J., \& Sehgal, S. (2018). Review of checkpoint immunotherapy for the management of non-small cell lung cancer. Immuno Targets and therapy, 7, 63.

84. Posey Jr, A. D., Schwab, R. D., Boesteanu, A. C., Steentoft, C., Mandel, U., Engels, B., \& Cogdill, A. P. (2016). Engineered CAR T cells targeting the cancer-associated Tn-glycoform of the membrane mucin MUC1 control adenocarcinoma. Immunity, 44(6), 1444-1454.

85. Butts, C., Murray, N., Maksymiuk, A., Goss, G., Marshall, E., Soulières, D., \& Davis, M. (2005). Randomized phase IIB trial of BLP25 liposome vaccine in stage IIIB and IV non-small-cell lung cancer. Journal of Clinical Oncology,23(27), 6674-6681.

86. Giaccone, G., Debruyne, C., Felip, E., Chapman, P. B., Grant, S. C., Millward, M., \& Zatloukal, P. (2005). Phase III study of adjuvant vaccination with Bec2/bacille Calmette-Guerin in responding patients with limited-disease small-cell lung cancer (European Organisation for Research and Treatment of Cancer 08971-08971B; Silva Study). Journal of clinical oncology, 23(28), 6854 6864.

87. Kirkwood, J. M., Butterfield, L. H., Tarhini, A. A., Zarour, H., Kalinski, P., \& Ferrone, S. (2012). 
Immunotherapy of cancer in 2012. CA: a cancer journal for clinicians, 62(5), 309-335.

88. Neninger, E., Díaz, R. M., de la Torre, A., Rives, R., Díaz, A., Saurez, G., ... \& Combet, T. (2007). Active immunotherapy with 1E10 anti-idiotype vaccine in patients with small cell lung cancer: report of a phase I trial. Cancer biology \& therapy, 6(2), 145-150.

89. Marcias, A. E. (2006). Compassionate study use of 1E10/Aluminium anti-idiotype vaccine in patients with advanced non-small-cell lung cancer (NSCLC): preliminary report. Annals of Oncology, 17, S9.

90. Leichman, G., Gravenor, D., Woytowitz, D., Mezger, J., Albert, G., Schmalbach, T. \& Manegold, C. (2005). CPG 7909, a TLR9 agonist, added to first line taxane/platinum for advanced non-small cell lung cancer, a randomized, controlled phase II study. Journal of Clinical Oncology, 23(16_suppl), 7039-7039.

91. Aerts, J. G., Lievense, L. A., Hoogsteden, H. C., \& Hegmans, J. P. (2014). Immunotherapy prospects in the treatment of lung cancer and mesothelioma. Translational lung cancer research, 3(1), 34.

92. Bell, K. J., Del Mar, C., Wright, G., Dickinson, J., \& Glasziou, P. (2015). Prevalence of incidental prostate cancer: A systematic review of autopsy studies. International journal of cancer, 137(7), 1749-1757.

93. Vansteenkiste, J., Zielinski, M., Linder, A., Dahabre, J., Esteban, E., Malinowski, W., ... \& Brichard, V. G. (2007). Final results of a multicenter, double-blind, randomized, placebocontrolled phase II study to assess the efficacy of MAGE-A3 immunotherapeutic as adjuvant therapy in stage IB/II non-small cell lung cancer (NSCLC). Journal of clinical oncology, 25(18_suppl), 7554-7554.

94. Barve, M., Bender, J., Senzer, N., Cunningham, C., Greco, F. A., McCune, D., \& Ganesa, P. (2008). Induction of immune responses and clinical efficacy in a phase II trial of IDM-2101, a 10-epitope cytotoxic T-lymphocyte vaccine, in metastatic non-small-cell lung cancer. Journal of Clinical Oncology, 26(27), 4418-4425.

95. Ramlau, R., Quoix, E., Rolski, J., Pless, M., Lena, H., Lévy, E., ... \& Limacher, J. M. (2008). A phase II study of Tg4010 (Mva-Muc1-I12) in association with chemotherapy in patients with stage III/IV Non-small cell lung cancer. Journal of Thoracic Oncology, 3(7), 735-744.

96. Bolonaki, I., Kotsakis, A., Papadimitraki, E., Aggouraki, D., Konsolakis, G., Vagia, A., ... \& Cordopatis, P. (2007). Vaccination of Patients With Advanced Non-Small-Cell Lung Cancer With an Optimized Cryptic Human Telomerase Reverse Transcriptase Peptide. Journal of clinical oncology, 25(19), 2727-2734.
97. Hirschowitz, E. A., Foody, T., Hidalgo, G. E., \& Yannelli, J. R. (2007). Immunization of NSCLC patients with antigen-pulsed immature autologous dendritic cells. Lung cancer, 57(3), 365-372.

98. Meyer, R. G., Korn, S., Micke, P., Becker, K., Huber, C., Wölfel, T., \& Buhl, R. (2007). An open-label, prospective phase I/II study evaluating the immunogenicity and safety of a ras peptide vaccine plus GM-CSF in patients with non-small cell lung cancer. Lung Cancer, 58(1), 88-94.

99. Brunsvig, P. F., Aamdal, S., Gjertsen, M. K., Kvalheim, G., Markowski-Grimsrud, C. J., Sve, I., \& Gaudernack, G. (2006). Telomerase peptide vaccination: a phase I/II study in patients with non-small cell lung cancer. Cancer Immunology, Immunotherapy, 55(12), 1553-1564.

100. Nemunaitis, J., Meyers, T., Senzer, N., Cunningham, C., West, H., Vallieres, E., \& Pappen, B. (2006). Faze me trial of sequential administration of recombinant DNA and adenovirus expressing L523S protein in early stage non-small-cell lung cancer. Molecular Therapy, 13(6), 1185-1191.

101. Nemunaitis, J., Jahan, T., Ross, H., Sterman, D., Richards, D., Fox, B., \& Hege, K. (2006). Phase $1 / 2$ trial of autologous tumor mixed with an allogeneic GVAX ${ }^{\circledR}$ vaccine in advanced-stage non-small-cell lung cancer. Cancer gene therapy, 13(6), 555-562.

102. Morse, M. A., Garst, J., Osada, T., Khan, S., Hobeika, A., Clay, T. M., \& Hsu, D. H. (2005). A phase I study of dexosome immunotherapy in patients with advanced non-small cell lung cancer. Journal of translational medicine, 3(1), 9.

103. Aslan, A., Erdem, H., Celik, M. A., Sahin, A., \& Cankaya, S. (2019). Investigation of Insulin-Like Growth Factor-1 (IGF-1), P53, and Wilms' Tumor 1 (WT1) Expression Levels in the Colon Polyp Subtypes in Colon Cancer. Medical science monitor: international medical journal of experimental and clinical research, 25, 5510.

104. Mine, T., Gouhara, R., Hida, N., Imai, N., Azuma, K., Rikimaru, T., \& Yamada, A. (2003). Immunological evaluation of CTL precursororiented vaccines for advanced lung cancer patients. Cancer science, 94(6), 548-556.

105. Raez, L. E., Cassileth, P. A., Schlesselman, J. J., Sridhar, K., Padmanabhan, S., Fisher, E. Z., \& Podack, E. R. (2004). Allogeneic Vaccination with a B 7. 1 HLA-A Gene-Modified Adenocarcinoma Cell Line in Patients with Advanced Non-SmallCell Lung Cancer. Journal of clinical oncology, 22(14), 2800-2807

106. Alevizakos, M., Kaltsas, S., \& Syrigos, K. N. (2013). The VEGF pathway in lung cancer. Cancer chemotherapy and pharmacology, 72(6), 1169-1181.

107. Carradori, S., Secci, D., \& Petzer, J. P. (2018). MAO inhibitors and their wider applications: a 
patent review. Expert opinion on therapeutic patents, 28(3), 211-226.

108. Schrank, Z., Chhabra, G., Lin, L., Iderzorig, T., Osude, C., Khan, N., \& Puri, N. (2018). Current molecular-targeted therapies in NSCLC and their mechanism of resistance. Cancers, 10(7), 224.

109. Sharma, A., Subudhi, S. K., Blando, J., Vence, L., Wargo, J., Allison, J. P., \& Sharma, P. (2019). Anti-CTLA-4 Immunotherapy Does Not Deplete FOXP3+ Regulatory $\mathrm{T}$ Cells (Tregs) in Human Cancers-Response. Clinical cancer research: an official journal of the American Association for Cancer Research, 25(11), 3469.

110. Nirschl, C. J., \& Drake, C. G. (2013). Molecular pathways: coexpression of immune checkpoint molecules: signaling pathways and implications for cancer immunotherapy. Clinical cancer research, 19(18): 4917-4924.

111. Turner, C. T., Hiroyasu, S., \& Granville, D. J. (2019). Granzyme B as a therapeutic target for wound healing. Expert opinion on therapeutic targets, 23(9), 745-754.

112. Cunha, L. L., Marcello, M. A., Rocha-Santos, V., \& Ward, L. S. (2017). Immunotherapy against endocrine malignancies: immune checkpoint inhibitors lead the way. Endocrine-related cancer, 24(12), T261-T281.

113. Borghaei, H., Paz-Ares, L., Horn, L., Spigel, D. R., Steins, M., Ready, N. E., \& Barlesi, F. (2015). Nivolumab versus docetaxel in advanced nonsquamous non-small-cell lung cancer. New England Journal of Medicine,373(17), 16271639.

114. Herbst, R. S., Baas, P., Kim, D. W., Felip, E., Pérez-Gracia, J. L., Han, J. Y., \& Majem, M. (2016). Pembrolizumab versus docetaxel for previously treated, PD-L1-positive, advanced nonsmall-cell lung cancer (KEYNOTE-010): a randomised controlled trial. The Lancet, 387(10027), 1540-1550.

115. Reck, M., Rodríguez-Abreu, D., Robinson, A. G., Hui, R., Csőszi, T., Fülöp, A., \& O’Brien, M. (2016). Pembrolizumab versus chemotherapy for PD-L1-positive non-small-cell lung cancer. New England Journal of Medicine,375(19), 18231833.

116. Schmidt, L. H., Kümmel, A., Görlich, D., Mohr, M., Bröckling, S., Mikesch, J. H., \& MüllerTidow, C. (2015). PD-1 and PD-L1 expression in NSCLC indicate a favorable prognosis in defined subgroups. PloS one, 10(8).
117. Qin, A., Coffey, D. G., Warren, E. H., \& Ramnath, N. (2016). Mechanisms of immune evasion and current status of checkpoint inhibitors in non- small cell lung cancer. Cancer medicine, 5(9), 2567-2578.

118. Bruno, T. C., Ebner, P. J., Moore, B. L., Squalls, O. G., Waugh, K. A., Eruslanov, E. B., \& McCarter, M. D. (2017). Antigen-presenting intratumoral B cells affect CD4+ TIL phenotypes in non-small cell lung cancer patients. Cancer immunology research, 5(10), 898-907.

119. Ma, Q. Y., Huang, D. Y., Zhang, H. J., Wang, S., \& Chen, X. F. (2017). Function and regulation of LAG3 on CD4+ CD25-T cells in non-small cell lung cancer. Experimental cell research,360(2), 358-364.

120. Xu, L., Huang, Y., Tan, L., Yu, W., Chen, D., Lu, C., \& Zhang, Y. (2015). Increased Tim-3 expression in peripheral NK cells predicts a poorer prognosis and Tim-3 blockade improves NK cellmediated cytotoxicity in human lung adenocarcinoma. International immunopharmacology, 29(2), 635-641.

121. Huang, Y. H., Zhu, C., Kondo, Y., Anderson, A. C., Gandhi, A., Russell, A., \& Clayton, K. L. (2016). Correction: Corrigendum: CEACAM1 regulates TIM-3-mediated tolerance and exhaustion. Nature, 536(7616), 359-359.

122. National Cancer Institute. Physician Data Query (PDQ). Health Professional Version. Non-Small Cell Lung Cancer Treatment. 2019. https://www.cancer.gov/types/lung/hp/non-smallcell-lung-treatment-pdq [accessed 12 June 2019]

123. Mittal, V., El Rayes, T., Narula, N., McGraw, T. E., Altorki, N. K., \& Barcellos-Hoff, M. H. (2016). The microenvironment of lung cancer and therapeutic implications. In Lung Cancer and Personalized Medicine: Novel Therapies and Clinical Management (pp. 75-110). Springer, Cham.

124. Hilbe, W., Manegold, C., \& Pircher, A. (2012). Targeting angiogenesis in lung cancer-Pitfalls in drug development. Translational lung cancer research, 1(2), 122.

125. Rothwell, P. M., Wilson, M., Price, J. F., Belch, J. F., Meade, T. W., \& Mehta, Z. (2012). Effect of daily aspirin on risk of cancer metastasis: a study of incident cancers during randomised controlled trials. The Lancet, 379(9826), 1591-1601.

126. Mellman, I., Coukos, G., \& Dranoff, G. (2011). Cancer immunotherapy comes of age. Nature, 480(7378), 480-489. 